\title{
A seasonal comparison of trace metal concentrations in the tissues of Arctic charr (Salvelinus alpinus) in Northern Québec, Canada
}

\author{
Mackenzie Anne Clifford Martyniuk ${ }^{\mathrm{a}^{*}}$, Patrice Couture ${ }^{\mathrm{a}}$, Lilian Tran ${ }^{\mathrm{b}}$, Laurie Beaupréc, Nastassia Urien ${ }^{\mathrm{a}}$, Michael \\ Power $^{\mathrm{d}}$ \\ ${ }^{a}$ Institut National de la Recherche Scientifique - Centre Eau, Terre, Environnement, 490 Rue de la Couronne \\ Québec (Québec), Canada, G1K $9 A 9$ \\ ${ }^{b}$ Nunavik Research Centre, P.O. Box 179, Kuujjuaq (Québec), Canada, JOM 1CO \\ ${ }^{c}$ Makivk Corporation, 1111 Boulevard Dr. Frederik-Philips, Saint-Laurent, (Québec), Canada, H4M 2X6 \\ ${ }^{d}$ University of Waterloo, 200 University Avenue West, Waterloo (Ontario), Canada, N2L 3G1 \\ * Corresponding Author-Mackenzie Anne Clifford Martyniuk, MSc. \\ Institut national de la recherche scientifique \\ Quebec, QC, Canada \\ mackenzie_anne_clifford.martyiuk@ete.inrs.ca
}

\section{Abstract}

Ecotoxicological research detailing trace metal contamination and seasonal variation in the tissues of northern fishes such as Arctic charr (Salvelinus alpinus) has been poorly represented in the literature beyond examination of mercury. In an effort to address this, anadromous Arctic charr were collected from the Deception River watershed in the late summer and post-winter season, before quantifying seasonal and organotropic variations in dorsal muscle and liver concentrations of arsenic, cadmium, chromium, copper, nickel, lead, and zinc. Potential linkages with biological variables (fork length, age, and somatic condition) and indicators of feeding behaviour $\left(\delta^{13} \mathrm{C}\right.$ and $\left.\delta^{15} \mathrm{~N}\right)$ were also assessed. Trace metal organotropism favouring elevation in liver tissue concentrations was exhibited by cadmium, copper, nickel and zinc, while arsenic, chromium and lead exhibited no significant organotropic variation. Seasonal differences in concentrations were metal and tissue dependent, but generally increased in tissues collected from post-winter sampled Arctic charr. Significant correlations with biological and trophic descriptors were also determined to be element and tissue dependent. These parameters, in addition to season, were incorporated into multi-predictor variable models, where variations in trace metal concentration data were often best explained when season, somatic condition, and trophic descriptors were included. These variables were also of greatest relative importance across all considered trace metals and tissue types. These findings suggest that seasonally linked processes have the greatest influence on trace metal concentrations in anadromous Arctic charr. Future metal-related research on Arctic charr and other northern fish species should further consider these variables when evaluating elemental accumulation.

\section{Keywords}

Arctic charr, Salvelinus alpinus, trace metal contamination, Québec, Nunavik, seasonal variation

\section{Acknowledgements}

We wish to thank Makivik Corporation and the Nunavik Research Centre, the Raglan Mine, Qaqqalik Landholding Corporation, the Ministère de la Forêt de la Faune et des Parcs, Mitacs, the Société du Plan Nord, and the Natural Sciences and Engineering Research Council (discovery grants awarded to M. Power and P. Couture) for logistical and financial support. Additionally, we wish to extend our gratitude to A. and S. Tayara for assistance with field work, as well as individuals at the University of Waterloo and Institut National de la Recherche Scientifique Centre Eau Terre Environnement for help with laboratory analysis. 
Introduction

Uptake and handling of trace metals by fish can depend on the variability and interaction of abiotic factors, (e.g., temperature, pH, water hardness) (Karthikeyan et al. 2007; Köck et al. 1996; Qu et al. 2014) and organism biology and physiology (e.g., feeding, age, somatic condition, growth) (Farkas et al. 2003; Greenfield et al. 2001; Sörensen 1991). Additionally, some metal dependent biomagnification in the food web can occur (Ikemoto et al. 2008; Jara-Marini et al. 2009; Zhao et al. 2013) and seasonal variations of trace metals in fish tissues have been reported (Audet and Couture 2003; Kahilainen et al. 2016; Keva et al. 2017). However, despite the dynamic processes associated with trace metal uptake and handling in fish, ecotoxicological research exploring trace metal contamination in northern fishes, such as Arctic charr (Salvelinus alpinus), has been poorly represented in the literature beyond examination of mercury (Hg) concentrations (Dallinger et al. 1997; Gantner et al. 2009; Köck et al. 1996).

Throughout their circumpolar distribution, Arctic charr are valued for their significant dietary contribution and cultural importance to northern peoples, such as the Inuit (Blanchet and Rochette 2008; Kuhnlein and Receveur 2007). While Hg is a contaminant of specific concern to northern peoples due to its neurologically toxic health effects (Mergler et al. 2007) and ability to biomagnify in aquatic food webs (Kidd et al. 1995; van der Velden et al. 2013a), other non-essential and essential metals at high concentrations can also have negative implications for human (Plum et al. 2010; Smith and Steinmaus 2009) and fish health (Ghosh et al. 2006; Mishra and Mohanty 2008). Therefore, the study and quantification of trace metals will increase understanding of the accumulation patterns of essential and non-essential metals in northern fish such as Arctic charr and provide insight into factors that may influence accumulation levels. Additionally, trace metal studies of northern fishes will aid in determining the potential for human exposure risks, especially given the importance and ubiquity of fish such as Arctic charr in the diet of northern Indigenous peoples (Huet et al. 2012; Kuhnlein and Receveur 2007). For example, the seasonal migration of Arctic charr between freshwater and marine environments for summer feeding (Dutil 1986; Rikardsen et al. 2003) suggests that trace metal uptake may vary seasonally because of the noted differences in marine and freshwater chemistry. In many parts of the north where there are seasonal winter fisheries for Arctic charr (Boivin and Power 1990), the potential for seasonal variations in trace metal contamination similarly implies differential seasonal exposure risks for humans. 
When coupled with trace metal analysis, stable isotope analyses can be used to infer patterns of trace metal 74 accumulation in aquatic food webs (Atwell et al. 1998; Croteau et al. 2005; Ikemoto et al. 2008). For example, the 75 relative abundance of carbon $\left({ }^{13} \mathrm{C} /{ }^{12} \mathrm{C}\right)$ and nitrogen $\left({ }^{15} \mathrm{~N} /{ }^{14} \mathrm{~N}\right)$ stable isotopes allow inferences to be made about fish 76 habitat use (Murdoch and Power 2013), geographic distribution (Campana et al. 2000), ontogenetic life history traits 77 (Grey 2001), and feeding relationships (Bearhop et al. 1999; Vander Zanden et al. 1998). Unlike stomach content 78 analysis, which only documents recent feeding, stable isotope analyses describe predator prey trophic interactions 79 over longer periods of time (Fry and Sherr 1989; Peterson and Fry 1987), typically months in northern fishes 80 (Hesslein et al. 1993). As nitrogen stable isotope values are consistently incremented with trophic transfer (DeNiro and Epstein 1981; Minagawa and Wada 1984), the values can be used to indicate food web position (Cabana and

82 Rasmussen 1994; Post 2002) and can be correlated with trace metal concentrations to estimate biomagnification rates (Croteau et al. 2005; Gantner et al. 2009; van der Velden et al. 2013a). In contrast, carbon stable isotope values remain relatively constant during trophic transfer (DeNiro and Epstein 1981; Fry and Sherr 1989; Vander Zanden and Rasmussen 2001), but can provide insight into feeding location or habitat use (Hecky and Hesslein 1995; Ofukany et al. 2014; Power et al. 2002). Here we analyzed dorsal muscle and liver tissue samples collected from anadromous Arctic charr in the Deception River system of Nunavik, Québec, Canada for trace metal concentrations and combined the data with comeasured biological information and stable isotope ratios to describe relationships between observed concentrations and patterns of trace metal accumulation. Specifically, collected data were used to test the hypotheses that: (i)

91 concentrations of essential (copper $(\mathrm{Cu})$ and zinc $(\mathrm{Zn}))$ and non-essential metals (arsenic (As), cadmium (Cd), 92 chromium $(\mathrm{Cr})$, nickel $(\mathrm{Ni})$, and lead $(\mathrm{Pb}))$ in dorsal muscle and liver tissues of anadromous Arctic charr would 93 differ significantly by tissue type, with concentration values determined from liver tissue being greater than in dorsal 94 muscle samples (Pannetier et al. 2016; Pyle et al. 2005); (ii) concentrations would vary seasonally and be elevated in 95 samples collected during the winter months (Cizdziel et al. 2002; Kahilainen et al. 2016; Keva et al. 2017); (iii) concentrations would be positively correlated with fork length and age (Al-Yousuf et al. 2000; Köck et al. 1996; Yi

97 and Zhang 2012), but decline as somatic condition increased (Eastwood and Couture 2002; Maes et al. 2005;

98 Swanson and Kidd 2010); and (iv) concentrations would be positively correlated with trophic position (Croteau et al. 
2005; Gantner et al. 2009; Soto-Jiménez et al. 2011), but negatively correlated with the carbon stable isotope gradient (Ofukany et al. 2014; Power et al. 2002).

In addition, we aimed to determine whether trace metal concentrations could be better described by multi variable statistical models inclusive of combinations of the variables listed above and their interactions. Specifically, models of variation for essential metals $(\mathrm{Cu}$ and $\mathrm{Zn})$ were expected to be better descriptors of the data when including information on trophic position and/or feeding strategies (represented by $\delta^{15} \mathrm{~N}$ and $\delta^{13} \mathrm{C}$, respectively) and season as a result of the uptake processes associated with these trace metals (Bury et al. 2003; Kamunde et al. 2002; Mathews and Fisher 2009) and the dominance of seasonal summer feeding exhibited by anadromous Arctic charr. In contrast, non-essential metals ( $\mathrm{As}, \mathrm{Cd}, \mathrm{Cr}, \mathrm{Ni}$, and $\mathrm{Pb}$ ) were expected to be better described by models inclusive of biological descriptors (fork length and/or age), trophic position $\left(\delta^{15} \mathrm{~N}\right)($ Gantner et al. 2009; Köck et al. 1996; SotoJiménez et al. 2011) and season, as these variables are known to significantly influence measured trace metal concentrations in fish tissue (Agah et al. 2009; Kahilainen et al. 2016; Wiener et al. 2003).

\section{Methods}

\section{Study Area}

The Deception River and tributaries (Fig. 1) span an area of $3870 \mathrm{~km}^{2}$ between latitudes $61^{\circ} 31^{\prime} 26^{\prime \prime} \mathrm{W}$ and $62^{\circ} 11^{\prime} 01^{\prime}$ N and are located approximately $60 \mathrm{~km}$ east of Salluit, Nunavik, Québec. The river flows into Deception Bay on the south side of the Hudson Strait, a deep and wide channel that connects Hudson Bay and the Foxe Basin with the Labrador Sea and the Davis Strait. The growing season in the region is less than 120 days per year and average daily temperatures range from $-25.6^{\circ} \mathrm{C}$ in February, to $10.5^{\circ} \mathrm{C}$ in August (Environment Canada 2018a; Environment Canada 2018b). In addition to traditional hunting and fishing activities, the area is home to two nickel and copper mining projects, Glencore - the Raglan Mine Project and Canadian Royalties Inc. - the Nunavik Nickel Project, and was also the site of the now shuttered Asbestos Hill Mine (Purtiniq). Mine personnel are present yearround and a $95 \mathrm{~km}$ road, that follows the Deception River and its tributaries closely for most of its length and connects Raglan's main mine site with additional camps and a deep water port on Deception Bay. Arctic charr spawn and overwinter in the Deception River headwater lakes Duquet (Inuit name: Tasialujjuaq) $62^{\circ} 03^{\prime} 18 \mathrm{~N}$, $74^{\circ} 31^{\prime} 51 \mathrm{~W}$ and Françoys-Malherbe (Inuit name: Pangaligiak) 62 $00^{\circ} 06 \mathrm{~N}, 74^{\circ} 15^{\prime} 25 \mathrm{~W}$ from October to June. The lakes are connected, respectively, to Deception Bay by 2.5 and $15 \mathrm{~km}$ stretches of river. For beneficiaries, most 
years there is a commercial fishing permit active for both lakes and Deception Bay, while a Raglan sport fishing

127

permit is active for Deception Bay. Some contaminant input is believed to result from the existing mining facilities proximate to Deception Bay, as well as atmospheric deposition. Lake Watts, a third lake in the Deception River system is assumed to have received some direct input of mining waste from the Asbestos Hill Mine prior to its closure in 1984. Traditional knowledge suggests that Arctic charr are predominately resident in Lake Watts and owing to its remote location access to the lake was not possible during the course of this study.

\section{Sample Collection}

Summer sampled anadromous Arctic charr were captured via experimental gill net $(25-150 \mathrm{~mm}$ mesh panels with a length of $120 \mathrm{~m}$ and a hanging depth of $2 \mathrm{~m}$ ) from eight locations in Deception Bay and the mouth of the Deception River in August of 2016 as fish were migrating upstream. A post-winter sample was obtained from Lake Françoys-Malherbe and Lake Duquet in May 2017, approximately a month prior to ice break up (Canadian Ice Service 2018). Post-winter samples were collected via jigging lines throughout the lakes by Nunavik Research Centre (NRC) staff in collaboration with the Elder's Spring Fishing Event hosted by Qaqqalik Landholding Corporation and supported by the Raglan Mine. All fish were sacrificed after capture with a sharp blow to the head. In the laboratory, all captured Arctic charr were weighed (mass $\pm 1 \mathrm{~g}$ ) and measured for fork length $( \pm 1$ $\mathrm{mm})$ and the measurements were used to calculate Fulton's condition factor $\left(\mathrm{K}=10^{5} * \mathrm{~W} / \mathrm{L}^{3}\right)$ after confirming isometric growth (Ricker 1975), which was determined by testing the slope of standardized weight-length regressions for significant deviations from a value of three (Ricker 1975). Liver tissue, as well as a sample of dorsal muscle tissue (mass $\approx 10 \mathrm{~g}$ wet weight) that was removed from above the lateral line, posterior to the dorsal fin on the left side of each Arctic charr (van der Velden et al. 2013a) were then immediately frozen at $-20^{\circ} \mathrm{C}$ for subsequent analyses (summer $n=32$, post-winter $n=35$ ). Sampled tissues were placed in Eppendorf polypropylene tubes that had been acid washed in $15 \% \mathrm{HNO}_{3}$ for at least 24 hours before being rinsed 5 times with distilled water, twice with ultrapure water, and then dried under a laminar-flow fume hood before use to minimize accidental metal contamination. The upper gastrointestinal tracts (e.g. esophagus and stomach) of all Arctic charr collected during post-winter sampling were examined for evidence of short-term winter feeding, while the anadromy of these fish was confirmed with $\delta^{34} \mathrm{~S}$ stable isotope analysis following Doucett et al. (1999). Fish ages were determined by NRC 
staff by submersing otoliths in water and examining the distal surface with reflected light under a dissecting microscope (Chilton and Beamish 1982).

\section{Stable Isotope Analysis}

Stable isotope analyses were performed at the Environmental Isotope Laboratory at the University of Waterloo (Waterloo, Ontario, Canada) with a Delta Plus Continuous Flow Stable Isotope Ratio Mass Spectrometer (Thermo Finnigan, Bremen, Germany) coupled to a Carlo Erba Elemental Analyzer (CHNS-O EA1108, Carlo Erba, Milan, Italy) following methods described in van der Velden et al. (2013a). Dorsal muscle tissue was dried at $50^{\circ} \mathrm{C}$ for $48 \mathrm{~h}$ and then pulverized into a homogenate powder with a mortar and pestle before being weighed to $0.275-$ $0.300 \mathrm{mg}$ (UMX2, Mettler-Toledo GmbH, Greifensee, Switzerland) and simultaneously analyzed for stable carbon and nitrogen stable isotopes $\left(\delta^{13} \mathrm{C}, \delta^{15} \mathrm{~N}\right)$. All measurements were expressed using standard delta notation $(\delta)$ as:

$$
\delta=\left[\frac{R_{\text {sample }}-R_{\text {standard }}}{R_{\text {standard }}}\right] \times 1000
$$

Where $R$ is the measured ratio of the abundance of the heavy to the light isotope in the sample or the standard. International reference standards used included Vienna Peedee Belemnite (Craig 1957) for $\delta^{13} \mathrm{C}$ analyses and nitrogen gas in the atmosphere (Mariotti 1983) for $\delta^{15} \mathrm{~N}$ analyses. Machine analytical precision for $\delta^{13} \mathrm{C}$ and $\delta^{15} \mathrm{~N}$, respectively, was determined to be $\pm 0.2 \%$ and $\pm 0.3 \%$ and was established by repeat analyses of internal laboratory working standards (IAEA- $\mathrm{N}_{1}+\mathrm{N}_{2}$, IAEA- $\mathrm{CH}_{3}+\mathrm{CH}_{6}$ ) cross calibrated to International Atomic Energy Agency (IAEA) standards: $\mathrm{CH}_{6}$ for $\delta^{13} \mathrm{C}$ and $\mathrm{N}_{1}$ and $\mathrm{N}_{2}$ for $\delta^{15} \mathrm{~N}$. Internal standards were placed at the beginning, middle and end of every run of samples to control for analytical drift. Repeatability was assessed by repeat analysis of 1 in 10

170 samples. Reported $\delta^{13} \mathrm{C}$ values were not normalized for lipid content as the $\mathrm{C}: \mathrm{N}$ ratios were consistently below the 1714.0 threshold above which extraction is required (Jardine et al. 2011; Logan et al. 2008; Sanderson et al. 2009).

\section{Trace Metal Analysis}

Trace metal analyses were performed at the Institut National de la Recherche Scientifique - Centre Eau

174 Terre Environnement (INRS-ETE) in Québec City, Québec, Canada. After lyophilisation for 72 hours (FTS Systems 175 TMM, Kinetics Thermal Systems, Longueuil, QC, Canada), freeze-dried samples were weighed to 0.100-0.150 g \pm $1760.1 \mathrm{mg}$ (XS205 DualRange Analytical Balance, Mettler Toledo, Mississauga, ON, Canada) to determine dry weight 177 (dw). Samples were then digested in $1 \mathrm{ml}$ nitric acid (70\%, v/v, Optima grade, Fisher Scientific, Whitby, ON, 
Canada) for 3 days at room temperature before being heated at $60^{\circ} \mathrm{C}$ for 2 hours. After samples had cooled, $0.5 \mathrm{ml}$ hydrogen peroxide (30\%, v/v, Optima grade, Fisher Scientific, Whitby, ON, Canada) was added and the sample was again heated at $60^{\circ} \mathrm{C}$ for 2 hours. The final digestion volume of $10 \mathrm{ml}$ was reached through dilution with ultrapure water. Concentrations of $\mathrm{As}, \mathrm{Cd}, \mathrm{Cr}, \mathrm{Cu}, \mathrm{Ni}, \mathrm{Pb}$, and $\mathrm{Zn}$ were then quantified using inductively coupled plasma mass spectrometry (ICP-MS) (XSERIES 2, Thermo Fisher Scientific, Winsford, England, UK), with results reported in $\mathrm{mg} / \mathrm{kg} \mathrm{dw}$.

Certified reference materials from the National Research Council of Canada (NRCC) TORT-3 (Lobster hepatopancreas, National Research Council of Canada, NRCC, Halifax, NS, Canada), DOLT-4 (Dogfish liver, National Research Council of Canada, NRCC, Halifax, NS, Canada), and blanks were subjected to the same digestion procedure and analyzed concurrently. Mean percent recoveries \pm standard deviations of TORT-3 analyzed in conjunction with dorsal muscle and liver tissue of Deception Bay Arctic charr captured during the summer of 2016 were within the certified ranges for As $(104 \% \pm 10 \%, n=2), \mathrm{Cd}(96 \% \pm 10 \%, n=2), \mathrm{Cu}(88 \% \pm 8 \%, n=2)$, $\mathrm{Ni}(86 \% \pm 8 \%, n=2), \mathrm{Pb}(90 \% \pm 6 \%, n=2)$ and $\mathrm{Zn}(94 \% \pm 9 \%, n=2)$. Mean percent recoveries \pm standard deviations of DOLT-4 were as follows: for As $(97 \% \pm 5 \%, n=3), \mathrm{Cd}(110 \% \pm 5 \%, n=3), \mathrm{Cu}(111 \% \pm 10 \%, n=3)$, $\mathrm{Pb}(84 \% \pm 1 \%, n=3)$ and $\mathrm{Zn}(113 \% \pm 5 \%, n=3)$. Recovery of Cr was below the certified ranges for TORT-3, while no certified value for Cr exists for DOLT $-4(53 \% \pm 3 \%, n=2$ and N/A $n=3$, respectively). Ni was below the certified range for DOLT-4 $(63 \% \pm 8 \%, n=2)$. Mean percent recoveries \pm standard deviations of TORT-3 analyzed in conjunction with dorsal muscle and liver tissue collected during the post-winter sampling period in May 2017 were within the certified ranges for As $(108 \% \pm 3 \%, n=3), \mathrm{Cd}(100 \% \pm 3 \%, n=3), \mathrm{Cu}(91 \% \pm 3 \%, n=3), \mathrm{Ni}(83 \%$ $\pm 2 \%, n=3), \mathrm{Pb}(100 \% \pm 4 \%, n=3)$ and $\mathrm{Zn}(107 \% \pm 3 \%, n=3)$. DOLT -4 mean percent recoveries \pm standard deviations were within ranges for $\mathrm{As}(92 \% \pm 1 \%, n=3), \mathrm{Cd}(109 \% \pm 2 \%, n=3), \mathrm{Cu}(107 \% \pm 2 \%, n=3), \mathrm{Pb}(111 \%$ $\pm 3 \%, n=3)$ and $\mathrm{Zn}(119 \% \pm 2 \%, n=3)$ as well. Recovery of $\mathrm{Cr}$ was below certified ranges for TORT-3 (57\% \pm 3\% $n=3$ ), while mentioned previously, no certified value for Cr exists for DOLT-4. Additionally, Ni was below the certified range for DOLT-4 $(48 \% \pm 8 \%, n=3)$. Recoveries below certified ranges $(\mathrm{Ni}$ and $\mathrm{Cr}$ ) suggest that the tissue metal concentrations presented may be underestimated compared with the true values for the specified elements. However, trace metal concentration data may still be used for statistical analysis (e.g. (Lee et al. 2006; Lohan et al. 
2001; Solis et al. 2009; Tam and Yao 1998) and obtained recovery rates should have no additional influence on the interpretation of relationships between measured concentrations and additional collected data.

\section{Statistical Analysis} perform all statistical analyses. Compliance of data to the assumptions of normality and homoscedasticity was determined through assessment of residual diagnostic histograms, visual assessment of Q-Q plots, and with use of the Shapiro-Wilk W test (Shapiro and Wilk 1965). All data that did not meet parametric assumptions were $\log _{10}$ transformed (Zar 2007). Student's t-tests or Mann-Whitney U tests were used to determine significant differences between tissue types and seasons (Zar 2007). Linear regressions were estimated to determine the relationship significance between trace metal concentration data and fork length, age, somatic condition, $\delta^{13} \mathrm{C}$, and $\delta^{15} \mathrm{~N}$ for

214 dorsal muscle and liver tissue data separated by season of collection. Model residuals were examined to ensure 215 conformance with regression assumptions and outliers that may have unduly influenced regression results were 216 assessed using Cook's Distance statistic (Cook 1977) and subsequently removed as necessary. General linear model

217 (GLM) methods were used to construct the statistical models required for determining the importance of trophic,

218 feeding, biological, and seasonal factors for explaining variation in the concentrations of essential metals. GLM methods were also used to determine the importance of biological variables for explaining variation in the concentrations of the non-essential metals.

Correlations between measured dorsal muscle and liver trace metal concentrations and factors hypothesized

222 to significantly co-vary with them were assessed using Pearson correlation analysis (Online Resource 1

223 Supplementary Tables S1 - S7) and/or linear regression, with significant correlations and interactions (e.g. length vs 224 condition) included as candidate explanatory variables in the multi-predictor variable GLM models used to describe 225 the overall variation in trace metal concentrations. Model selection was performed using the Akaike Information

226 Criteria (AIC) adjusted for small sample sizes $(A I C c)$, with models including all combinations of potential predictor 227 variables as assessed above and a null model considered (Online Resource 1 Supplementary Tables S8 - S14). The model with the lowest $A I C c$ score was considered the most accurate. Where models for trace metal elements and

229 tissue types had $A I C c$ values differing by less than two, model averaging was used following methods outlined in 230 Lukacs et al. (2010). Model averaging reduces biases that may be introduced when using data to select a single 
231 "best" model from a large set of models that can imply different predictor values (Lukacs et al. 2010). The relative 232 importance of the parameters from the set of "best models" were determined by summing the Akaike weights of 233 each model that contained the parameter of interest and with the creation of the composite model, any parameter 234 with a relative importance weight $<0.5$ and inclusive of 0 in its $95 \%$ upper and lower confidence interval was 235 dropped from the resulting averaged model. Computational details for the additional statistics associated with the 236 AIC methodology and model averaging can be found in Burnham and Anderson (2003), Lukacs et al. (2010), and 237 Symonds and Moussalli (2011). 
Results

\section{Organotropism and Seasonal Variations}

A total of 32 Arctic charr were randomly sampled for matched dorsal muscle and liver samples from the

241 Deception Bay summer fishery and 35 similarly matched samples were obtained from the post-winter fishery for trace metal concentration analyses with ICP-MS. Samples from the post-winter season came almost equally from lakes Duquet $(n=18)$ and Françoys-Malherbe $(n=17)$. Stable isotope $\delta^{34} S$ analysis indicated $n=6$ fish from the

244 subset were non-anadromous ( $n=4$ from Lake Duquet and $n=2$ from Françoys-Malherbe) and these were excluded from further consideration.

Summary data (fork length, age, somatic condition, $\delta^{13} \mathrm{C}$ and $\delta^{15} \mathrm{~N}$ ) values for the anadromous Arctic charr on which trace metal analyses were performed are given in Table 1. Tests of the slope of standardized weight-length regressions indicated isometric growth in both the summer (slope $=-3.12$, t-test, $p=0.4569$ ) and post-winter (slope $=-3.03$, t-test, $p=0.2546$ ) and permitted the use of Fulton's $\mathrm{K}$ in additional statistical analyses. Fork length, age, and $\delta^{15} \mathrm{~N}$ values exhibited no significant seasonal variation, while somatic condition and $\delta^{13} \mathrm{C}$ values were significantly greater in Arctic charr captured in the marine environment. Additionally, examination of the upper gastrointestinal tract provided no evidence of short-term winter feeding.

Mean trace metal concentrations and ranges (essential and non-essential) for dorsal muscle and liver tissue

254 collected from Arctic charr captured during the summer sampling campaign in Deception Bay and the postwintering period are reported in Table 2 . In summer, liver concentrations were significantly greater than dorsal muscle concentrations for $\mathrm{As}, \mathrm{Cd}, \mathrm{Cu}, \mathrm{Ni}$, and $\mathrm{Zn}$, but not for $\mathrm{Cr}$, or $\mathrm{Pb}$. Similarly, in winter, the measured liver 257 concentrations were significantly greater than dorsal muscle concentrations for $\mathrm{Cd}, \mathrm{Cu}, \mathrm{Ni}$, and $\mathrm{Zn}$. However, in post-winter collected samples, $\mathrm{As}$ and $\mathrm{Pb}$ concentrations were not significantly different between tissue types, while 259 Cr concentrations were significantly greater in dorsal muscle tissue compared with liver.

All analyzed trace metals exhibited seasonal variations, but these variations were often tissue dependent

261 (Table 2). Chromium and $\mathrm{Pb}$ concentrations were significantly greater in dorsal muscle and liver tissue collected 262 from post-winter Arctic charr. Arsenic and $\mathrm{Cu}$ concentrations did not vary significantly by season in dorsal muscle 263 samples. Concentrations of the same trace metals did differ seasonally in liver, with As being higher in summer 264 sampled fish and $\mathrm{Cu}$ in post-winter captured Arctic charr. Nickel and $\mathrm{Zn}$ liver concentrations did not vary 
seasonally, whereas dorsal muscle concentrations for the same trace metals were significantly greater in post-winter

Arctic charr. Both dorsal muscle and liver Cd concentrations exhibited significant seasonal variation, with higher values in dorsal muscle in summer and higher values in liver in post-winter collected fish.

Quantification of trace metal concentrations determined all measured dorsal muscle values were below the regulatory $3.5 \mathrm{mg} \cdot \mathrm{kg}^{-1}$ of As in fish protein recommended in Health Canada's list of contaminants and other

270 adulterating substances in foods (Health Canada 2018). However, $\mathrm{n}=3$ fish from the summer and $\mathrm{n}=1$ fish from

271 the post-winter sampling period had liver As concentrations that registered higher than this value. Health Canada has

272 no existing guidelines for $\mathrm{Cd}$, but the Food and Agricultural Organization of the United Nations (FAO) standard

273 sets the limit of total $\mathrm{Cd}$ in edible fishery products at $0.05 \mathrm{mg} \cdot \mathrm{kg}^{-1}$, though the value is increased to $0.1 \mathrm{mg} \cdot \mathrm{kg}^{-1}$

274 depending on the species. $N=5$ dorsal muscle tissue samples from summer caught Arctic charr had Cd

275 concentrations greater than the $0.05 \mathrm{mg} \cdot \mathrm{kg}^{-1}$ guideline, while all liver samples exceeded the FAO limit. All dorsal

276 muscle and liver $\mathrm{Pb}$ concentrations determined for Arctic charr collected during both sampling periods were below

277 the regulatory $0.5 \mathrm{mg} \cdot \mathrm{kg}^{-1}$ of $\mathrm{Pb}$ in fish protein recommended in Health Canada's list of contaminants and other

278 adulterating substances in foods (Health Canada 2018). No existing Canadian or internationl regulatory guidance for

279 the consumption of fish tissue existed for $\mathrm{Cr}, \mathrm{Cu}, \mathrm{Ni}$, and $\mathrm{Zn}$ could be determined.

\section{Relationships with Biological Variables and Stable Isotope Values}

Significant relationships between dorsal muscle and liver concentrations of analyzed elements and fork

282 length, age, somatic condition, $\delta^{13} \mathrm{C}$, and $\delta^{15} \mathrm{~N}$ are plotted in Fig. $2-5$. Relationships were determined to be season

283 and tissue specific. Summer dorsal muscle As concentrations were not significantly related to any of the tested

284 variables. In contrast, post-winter As concentrations were significantly positively correlated with all tested variables 285 except somatic condition and $\delta^{13} \mathrm{C}$ (fork-length $\left(\mathrm{r}^{2}=0.28, p=0.0035\right)$; age $\left(\mathrm{r}^{2}=0.22, p=0.0111\right)$; and $\delta^{15} \mathrm{~N}\left(\mathrm{r}^{2}=\right.$

$2860.43, p=0.0001)$ ) (Fig. 2 and Fig. 4). Liver As and dorsal muscle Cd concentrations were not significantly related to

287 any of the tested variables in either summer or post-winter sampled Arctic charr. However, liver Cd concentrations

288 significantly declined as somatic condition increased in late summer sampled fish $\left(\mathrm{r}^{2}=0.30, p=0.0015\right)$ (Fig. 3).

289 Dorsal muscle $\mathrm{Cr}$ concentrations measured in late summer migrants significantly declined as trophic position

290 increased $\left(\mathrm{r}^{2}=0.12 p=0.0488\right)$ (Fig. 4), but no additional relationships were observed. 
Dorsal muscle $\mathrm{Cu}$ concentrations were not related to fork length, age, $\mathrm{K}$ values, $\delta^{13} \mathrm{C}$, or $\delta^{15} \mathrm{~N}$ in either season. However, $\mathrm{Cu}$ concentrations in summer and post-winter liver samples significantly increased with $\delta^{13} \mathrm{C}$

293 (summer $\left(\mathrm{r}^{2}=0.30, p=0.0011\right.$; post-winter $\left(\mathrm{r}^{2}=0.15, p=0.0346\right)$ (Fig. 5). Summer liver $\mathrm{Cu}$ and Ni concentrations 294 both declined as somatic condition increased $\left(\mathrm{Cu}\left(\mathrm{r}^{2}=0.13, p=0.0460\right) ; \mathrm{Ni}\left(\mathrm{r}^{2}=0.19 p=0.0132\right)\right.$ (Fig. 3), but for $\mathrm{Ni}$ there were no other significant relationships. Summer dorsal muscle and liver $\mathrm{Pb}$ concentrations were not significantly related to any of the investigated variables, but significantly declined as $\delta^{13} \mathrm{C}$ increased in the dorsal muscle of post-winter sampled fish $\left(\mathrm{r}^{2}=0.16, p=0.0368\right)$ (Fig. 4). No additional significant relationships between $\mathrm{Pb}$ concentrations and tested variables were determined for post-winter dorsal muscle or liver samples. condition, $\delta^{13} \mathrm{C}$, or trophic position. Summer liver $\mathrm{Zn}$ concentrations significantly negatively correlated with fork length $\left(\mathrm{r}^{2}=0.13, p=0.0415\right)$, somatic condition $\left(\mathrm{r}^{2}=0.31, p=0.0009\right)$, and trophic position $\left(\mathrm{r}^{2}=0.14 p=0.0331\right)$ (Fig. 3 and Fig. 5). Post-winter Zn concentrations in the dorsal muscle and liver significantly declined with fork length (dorsal muscle $\left(\mathrm{r}^{2}=0.40, p=0.0002\right)$; liver $\left.\left(\mathrm{r}^{2}=0.25, p=0.0067\right)\right)$ and trophic position (dorsal muscle $\left(\mathrm{r}^{2}=0.24, p\right.$ $=0.0074)$; liver $\left.\left(: \mathrm{r}^{2}=0.19, p=0.0177\right)\right)$ (Fig. 3, Fig. 4, and Fig. 5), but had no significant relationship with somatic condition, or $\delta^{13} \mathrm{C}$. Dorsal muscle $\mathrm{Zn}$ concentrations were significantly inversely correlated with fish age in postwinter fish $\left(\mathrm{r}^{2}=0.25, p=0.0060\right)$ (Fig. 2$)$, whereas liver concentrations showed no significant relationship.

\section{General Linear Models - Essential Metals $(\mathrm{Cu}, \mathrm{Zn})$}

The relative importance of individual parameters for explaining variation in dorsal muscle and liver concentrations of essential metals in Deception River Arctic charr are reported in Table 3. While no single

310 parameter dominated in all sets, the relative importance of season, fork length, and $\delta^{13} \mathrm{C}$ was high when summed 311 across all $A I C c$ determined models for describing variation in the data (Online Resource 1 Supplementary Tables S8 and S9). AICc analysis indicated no single model "best" described the data for either $\mathrm{Cu}$ or $\mathrm{Zn}$, with multiple

313 plausible models yielding $A I C c$ values within 2 of the "best" models. Composite models based on model averaging 314 of parameters across all plausible models are reported in Table 4 (dorsal muscle) and Table 5 (liver). Model averaging resulted in parameter estimate confidence limits that included zero in many instances, suggesting that the

316 associated parameters were not important in explaining variation in the observed data and concentrations of these 317 essential metals may be better described by parameters not included in our model set. No composite model could be 
318 determined for $\mathrm{Cu}$ dorsal muscle concentrations given the AICc equivalence of the estimated single parameter 319 models.

\section{General Linear Models - Non-Essential Metals (As, Cd, Cr, Ni, and Pb)}

The relative importance of individual parameters for explaining variation in dorsal muscle and liver

322 concentrations of non-essential metals in Deception River Arctic charr are presented in Table 4. As seen with

323 essential metals, no single parameter dominated in all data sets. However, the relative importance of season and

324 somatic condition was high when summed across all models that best described variation in the data, which were

325 determined through $A I C c$ model selection and were ranked as the most important variables, respectively, in seven of

326 ten and six of ten of the estimated non-essential metal models. For Arctic charr, it appears that seasonally and

327 physiologically dependent integrative processes have the largest impact on trace metal concentrations in this species.

328 However, AICc analysis indicated no single model "best" described the data for any of the considered non-essential

329 metals, with multiple plausible models yielding AICc values within 2 of the "best" models (Online Resource 1

330 Supplementary Tables S10 - S14). Composite models based on model averaging of parameters across all plausible

331 models are reported in Table 4 and Table 5. As with the essential metals, model averaging of non-essential metals

332 resulted in parameter confidence limits that included zero in many instances. 


\section{Discussion}

Higher liver than dorsal muscle trace metal concentrations were observed for some ( $\mathrm{Cd}, \mathrm{Cu}, \mathrm{Ni}, \mathrm{Zn})$, but not all $(\mathrm{As}, \mathrm{Cr}, \mathrm{Pb})$ trace metals. All analyzed trace metals exhibited seasonal variation, although results were often tissue dependent. Significant correlations with fork length, age, somatic condition and trophic descriptors $\left(\delta^{13} \mathrm{C}\right.$, $\delta^{15} \mathrm{~N}$ ) existed for some, but not all of the considered trace metals. Models of essential and non-essential metal concentrations were often inclusive of some of the hypothesized descriptor variables, but better explained variation in concentrations when multiple parameters were included. Across all considered trace metals and tissue types, season, somatic condition, and $\delta^{13} \mathrm{C}$ dominated as the variables of greatest relative importance. Fork length also appeared as a variable of high relative importance for essential metals, and age and $\delta^{15} \mathrm{~N}$ tended to be of greater relative importance to the non-essential metals. The majority of composite models for describing elemental tissue concentrations were often inclusive of the above noted parameters.

\section{Organotropism}

Trace metal organotropism was observed with $\mathrm{Cd}, \mathrm{Cu}, \mathrm{Ni}$, and $\mathrm{Zn}$ accumulation, with total liver trace metal concentrations being significantly greater than concentrations determined from dorsal muscle tissue. Elements As, $\mathrm{Cr}$, and $\mathrm{Pb}$ did not behave as predicted and exhibited no significant variation in concentrations among the analyzed tissue types. The organotropic pattern of preferential $\mathrm{Cd}, \mathrm{Cu}, \mathrm{Ni}$, and $\mathrm{Zn}$ liver accumulation has been observed with other fish species across several different families, e.g. Clupeidae, Caragidae, Mugilidae, Scombridae, and Serranidae (Canli and Atli 2003; Fernandes et al. 2007; Roméo et al. 1999), as the liver is one of the main sites for metal storage and detoxification in fish. Previous studies have established that trace metal concentrations in the liver are often elevated in relation to muscle tissue concentrations (Fernandes et al. 2007; Pannetier et al. 2016; Roméo et al. 1999), as a result of a targeting of metabolically active tissues by metals (Canli et al. 1998; Langston 2017; Roesijadi 1994). However, some exceptions to the general pattern have been noted and may be the consequence of species-specific physiology, feeding behaviour, and/or habitat use (Canli and Atli 2003; Kojadinovic et al. 2007; Pannetier et al. 2016), the preferential induction of metal binding proteins to certain elements over others (Allen 1994; Roesijadi 1994; Tulasi et al. 1992), or elemental elimination rates (Kalay and Canli 2000). Differences in lipid solubility of the specified metal and/or exposure duration and bioavailability (Cossa et al. 2011; Kainz and Fisk 2009; Reynders et al. 2006) may also have contributed to the observed variation in organotropism noted here. 
Measured $\mathrm{As}, \mathrm{Cr}$, and $\mathrm{Pb}$ concentrations exhibited no significant variation between dorsal muscle and liver.

361 The lack of significant differences for $\mathrm{Pb}$ accords with observations reported for marine fishes such as Skipjacks,

362 Katsuwonus pelamis, Swordfish, Xiphias gladius, and Yellowfin tunas, Thunnus albacares (Kojadinovic et al. 2007)

363 and has been hypothesized to be associated with $\mathrm{Pb}$ accumulation and distribution channels given the affinity for $\mathrm{Pb}$

364 uptake in mucosal membranes (gills/fins/skin/intestines) as opposed to muscle or liver tissues (Sörensen 1991).

365 Previous studies have also documented lower liver $\mathrm{Pb}$ accumulation when compared to other non-essential metals

366 (Allen 1994; Roesijadi 1994; Tulasi et al. 1992). Organotropism of As and Cr appears to vary by species (Pannetier

367 et al. 2016; Yilmaz et al. 2010). For example, higher hepatic $\mathrm{Cr}$ concentrations have been reported for the broad

368 striped anchovy, Anchoa hepsetus (Canli and Atli 2003) and the European catfish, Silurus glanis (Squadrone et al.

369 2013), while higher muscle concentrations have been observed in the Vietnamese catfish, Clarias fucus (Wagner

370 and Boman 2003). Additionally, no significant variation between muscle and liver tissue As concentrations has been

371 documented in American, Anguilla rostrata, and European eels, Anguilla anguilla (Pannetier et al. 2016).

372 Differences among species suggest that observed tissue concentrations may be related to exposure duration,

373 elemental kinetics, and/or the environmental bioavailability (Cossa et al. 2011; Sharif et al. 1993; Spry and Wood

374 1989), as these predictors have been previously associated with species-specific variations of trace metal

375 concentrations.

\section{Seasonal Variation}

The significantly greater post-winter tissue trace metal concentrations observed in this research are

378 consistent with data reported for other trace metals (e.g. Hg) and fish species (e.g. European whitefish (Coregonus

379 lavaretus)) (Kahilainen et al. 2016; Keva et al. 2017; Köck et al. 1996) and may result from the distinct patterns of

380 seasonal feeding behavior in Arctic charr (Dutil 1986; Rikardsen et al. 2003), as regulatory processes associated

381 with several of the analyzed trace metals are greatly influenced by diet (Bury et al. 2003; Handy 1996; Mathews and

382 Fisher 2009). Both feeding and metabolism increase in the summer, the latter as a result of increased water

383 temperatures and food intake (Jobling 1981; Van Leeuwen et al. 2012; Yang et al. 2000) and both factors have

384 implications for trace metal accumulation (Douben 1989; Nichols and Playle 2004; Yang et al. 2000). Seasonal

385 feeding and metabolic changes may then increase trace metal uptake and subsequent depuration rates (Nichols and

386 Playle 2004; Van Leeuwen et al. 2012; Yang et al. 2000), with the balance likely to favour depuration given the low 
concentration environments in which Arctic charr feed in the summer. For example, trace metal concentrations in marine environments are typically lower in comparison to freshwater counterparts (Grosell et al. 2007; VicenteMartorell et al. 2009), implying that trace metal uptake through feeding or across the gill via respiration will be lower in marine than freshwater environments (Loro et al. 2012; Zhang and Wang 2007). Thus, summer occupancy of marine environments would favour metabolically driven elimination of previously accumulated trace metals whereas winter occupancy of freshwater environments favours accumulation as a result of habitat-driven exposure and reduced metabolic-driven depuration. In addition to the reduced metabolically driven depuration of trace metals during the ice-covered period (Douben 1989; Jobling 1981; Van Leeuwen et al. 2012), winter reductions in body reserves and documented declines in somatic condition (Amundsen and Knudsen 2009; Jørgensen et al. 1997; Klemetsen et al. 2003) could

397 have significant implications for over-wintering trace metal concentrations. The phenomenon that has been termed starvation - concentration has been reported for $\mathrm{Hg}$ concentrations after seasonal protein and lipid loss (Cizdziel et al. 2003; Cizdziel et al. 2002) and condenses Hg in remaining tissues (Kahilainen et al. 2016) resulting in higher concentrations during the ice-covered period (Keva et al. 2017). As winter for anadromous Arctic charr is characterized by lipid and protein losses (Dutil 1986; Jørgensen et al. 1997) and somatic condition reductions, as 402 seen here and elsewhere (Amundsen and Knudsen 2009; Klemetsen et al. 2003), it is hypothesized that declines in 403 Arctic charr body reserves during the ice-covered period associated with the starvation - concentration phenomenon 404 similarly condense trace metal concentrations in the remaining tissues to produce the observed seasonal variation 405 and elevation of concentrations in post-winter sampled tissues. concentrations, found to be highest in summer. Arsenic bioavailability is greater in the marine environment (Cullen 408 and Reimer 1989; Seyler and Martin 1991) and an association between As concentrations and the influence of the 409 marine environment has been previously demonstrated in the American eel and the European eel in both Canada and 410 France (Pannetier et al. 2016). Thus, annual migrations and subsequent marine residency are sufficient to explain 411 elevated summer As concentrations. In contrast, observed variations in Cd concentrations are more likely related to 412 exposure time, uptake dynamics, and Cd distribution channels. For example, increased summer water temperatures 413 have been associated with elevated Cd uptake in fish (Douben 1989; Köck et al. 1996), while liver Cd 

1991) or organ uptake dynamics. Although greater concentrations of Cd can be found in tissues, such as the gills,

416 scales, and muscle, after initial dietary and aqueous exposure (Odžak and Zvonaric 1995; Sörensen 1991), prolonged

417 exposure results in significantly greater concentrations in liver and kidney tissue (Dang and Wang 2009; Odžak and Zvonaric 1995; Sörensen 1991).

While no formal Canadian consumption guidelines exist for $\mathrm{Cr}, \mathrm{Cu}, \mathrm{Ni}$, and $\mathrm{Zn}$, quantifying dorsal muscle and liver $\mathrm{As}, \mathrm{Cd}$, and $\mathrm{Pb}$ concentrations of summer and post-winter captured Arctic charr determined several samples exceeded consumption guidelines proposed by Health Canada and the FAO. All measured dorsal muscle values were below the regulatory $3.5 \mathrm{mg} \cdot \mathrm{kg}^{-1}$ of As in fish protein recommended in Health Canada's list of

423 contaminants and other adulterating substances in foods (Health Canada 2018), yet three fish from the summer and one fish from the post-winter sampling period had liver As concentrations that exceeded this value. For Cd, five summer dorsal muscle samples had concentrations greater than the $0.05 \mathrm{mg} \cdot \mathrm{kg}^{-1} \mathrm{FAO}$ guideline, while all liver samples exceed the value (FAO of the United Nations 2003). Finally, all dorsal muscle and liver Pb concentrations

427 were below the regulatory $0.5 \mathrm{mg} \cdot \mathrm{kg}^{-1}$ of $\mathrm{Pb}$ in fish protein recommended by Health Canada (Health Canada 2018).

428 As Arctic charr liver tissue is not generally consumed, trace metal concentrations in dorsal muscle tissue would be 429 of greatest concern to the local communities in regards to consumption. While some potential risk is apparent for Cd during the summer months, which may be the result of increased summer water temperatures facilitating Cd uptake (Douben 1989; Köck et al. 1996), seasonal risks associated with capture and consumption of anadromous Deception

432 River Arctic charr appear minimal. However, further evaluation of seasonal variation in trace metals in other

433 anadromous Arctic charr populations is suggested to better elucidate global patterns in uptake and accumulation.

434 Additionally, evaluation of consumption risks for resident Arctic charr is also advised given the higher winter 435 concentrations for THg detailed in other lacustrine resident Arctic charr populations (Kahilainen et al. 2016) and the 436 consistently higher THg concentrations in lacustrine life history forms (Swanson et al. 2011; Van der Velden et al. 437 2015; van der Velden et al. 2013b).

\section{Relationships with Biological Variables and Stable Isotope Values}

Observed relationships between As and fork length and age may be explained by the associations between 
441 with larger/older fish having experienced greater exposure to increased As bioavailability through their cumulative

442 annual migrations to the marine environment. Decreases in $\mathrm{Zn}$ with fish length likely depend on the association

443 between Zn and metabolism (Zhang and Wang 2007). The dilution effect with age mirrors results reported for other

444 fish species, e.g. Chinook salmon, Oncorhynchus tshawytscha and white sucker, Catostomus commersonii

445 (Chapman 1978; De Wet et al. 1994; Ney and Van Hassel 1983) and has been attributed to age-dependent decreases

446 in daily ration (Marmulla and Rösch 1990).

447 Several significant inverse relationships existed between tissue concentrations and K values, as seen here,

448 have been reported for elsewhere for Arctic charr (Swanson and Kidd 2010) and several other fish species, e.g.

449 European eel, and yellow perch, Perca flavescens (Dittman and Driscoll 2009; Eastwood and Couture 2002; Maes et

450 al. 2005). The negative relationships between trace metal concentrations and somatic condition may be attributed to

451 the dilution effect of lipids (Eisler 1987; Farkas et al. 2003; Kahilainen et al. 2016), as lipid content and K values

452 have been previously associated (Dutil 1986; Herbinger and Friars 1991; Thompson et al. 1991).

453 Measured $\mathrm{Pb}$ concentrations were inversely related to $\delta^{13} \mathrm{C}$, while $\mathrm{Cu}$ behaved in a manner opposite to what

454 was predicted. Relationships between $\mathrm{Pb}$ and $\delta^{13} \mathrm{C}$ would infer that increased feeding in marine influenced

455 environments promotes reduced $\mathrm{Pb}$ accumulation, and is likely associated with reported significant differences

456 between trace metal concentrations in freshwater vs. marine prey items (Evans et al. 2005). Previously documented

457 relationships between $\mathrm{Cu}$ and $\delta^{13} \mathrm{C}$ vary (Asante et al. 2008; Ofukany et al. 2014) and appear independent of species,

458 habitat use, and/or feeding (Bradley and Morris 1986; Kress et al. 1999; Pouil et al. 2017). Thus, species-specific

459 homeostatic regulation may have a greater influence on accumulation of $\mathrm{Cu}$ than environment in non-heavily

460 contaminated locations, which has been suggested in previous literature (Eastwood and Couture 2002; Pyle et al.

4612005 ; Rajotte and Couture 2002).

462 While As was influenced by trophic position as predicted, $\mathrm{Zn}$ and $\mathrm{Cr}$ exhibited biodiminution.

463 Biodiminution has been observed previously with other aquatic organisms and fish (Borrell et al. 2016; Bungala et

464 al. 2017; Kraemer et al. 2012) and has been attributed to food web simplicity for Zn (Cardwell et al. 2013) with

465 generally no biomagnification of this element occurring when food chains consist of only primary producers,

466 macroinvertebrate consumers, and fish. Considering the aquatic habitats and communities in which Arctic charr

467 reside and feed are relatively simple (Christoffersen et al. 2008) and the relatively lower trophic position of Arctic 
468 charr when feeding in the marine environment (Linnebjerg et al. 2016), this may suggest that the observed 469 biodiminution of $\mathrm{Zn}$ is the result of food web interactions. The trend for $\mathrm{Cr}$ may be the result of poor accumulation 470 of this element from the environment (Bungala et al. 2017) in conjunction with elemental half-life and storage

471 properties that can prompt concentration reductions during food web trophic transfers (Campbell et al. 2005;

472 Nordberg 1998; Rabinowitz 1991).

473 The lack of consistent single variable relationships between trace metal concentrations and the fish

474 biological descriptors considered, e.g. length or age, suggests that these variables are not the best descriptors of

475 elemental concentrations in anadromous Arctic charr. Rather, concentration data were better described when season,

476 somatic condition, or trophic descriptors $\left(\delta^{13} \mathrm{C}\right.$, and $\left.\delta^{15} \mathrm{~N}\right)$ were included in predictive models. Thus, for Arctic charr

477 it appears that seasonally and physiologically dependent integrative processes have the greatest influence on trace

478 metal concentrations in this species as has been documented previously in the literature for species such as rainbow

479 trout and winter flounder, Pseudopleuronectes americanus (Glover and Hogstrand 2002; Kamunde et al. 2002;

480 Shears and Fletcher 1979). It is where $\left(\delta^{13} \mathrm{C}\right)$, when (season), and how successfully (K) an individual feeds that are

481 important for determining among-individual trace metal concentration variations, further suggesting that future

482 studies consider seasonality and seasonally driven processes when evaluating trace metal accumulation for this

483 species.

484 Conclusions

This research has provided one of the first studies of the biological and trophic factors thought to be significant for explaining variations in trace metal concentrations in anadromous Arctic charr. Observed

487 organotropism was generally consistent with previous literature observations, while seasonal differences in 488 concentrations appear to be linked to seasonally regulated metabolic depuration and elimination processes in 489 association with habitat driven exposure and winter fasting induced concentration of tissue trace metals. However, 490 further work is necessary to elucidate global patterns of seasonal trace metal accumulation for Arctic charr, 491 especially as seasonal trends may differ between life history forms for this species. Relationships with fork length, 492 age, and somatic condition, as well as stable isotope values were dependent on the element of interest as well as the 493 analyzed tissue and provided no consistency in terms of explanatory power as hypothesized. Predictive models of 494 concentration data were best described when multiple variables were included. Multi-predictor variable models of 
tissue concentration data improved abilities to explain variations in the data and were often best supported when season, somatic condition, and trophic descriptors were included in the model. Results highlight the influence of

497 these variables on the uptake and handling of trace metals in anadromous Arctic charr and suggest that seasonally

498 and physiologically dependent integrative processes have the largest influence on trace metal concentrations in 499 anadromous Arctic charr. Overall, this research highlights the importance of seasonal dynamics on trace metal 500 accumulation for anadromous Arctic charr and suggests that future studies further consider seasonally associated 501 processes when evaluating elemental uptake in this species.

\section{Compliance with Ethical Standards}

503 1. Funding: financial support for this project was provided by Mitacs Accelerate Internship, NSERC Discovery Grants awarded to Michael Power and Patrice Couture, Makivik Corporation, the Raglan Mine, and Société du Plan Nord.

2. Conflict of Interest: All the authors declare that they have no conflict of interest.

3. Ethical approval: This article does not contain any studies with human participants performed by any of the authors. Sample collection of animals was performed in accordance with standards dictated by the Ministère des Forêts, de la Faune, et des Parcs - Direction de la gestion de la faune du Nord-du-Québec (permis de gestion de la faune \#2016-02-199-152-10-G-P N/D : 9053_36)

4. Informed Consent: Informed consent was not required, as this research did not require human participants, their data or biological material. Additionally, all information is anonymized and the submission does not include images that may identify any people. 


\section{References}

Agah H, Leermakers M, Elskens M, Fatemi SM, Baeyens W (2009) Accumulation of trace metals in the muscle and liver tissues of five fish species from the Persian Gulf. Environ Monit Assess 157:499-514 doi:10.1007/s10661-008-0551-8

Al-Yousuf MH, El-Shahawi MS, Al-Ghais SM (2000) Trace metals in liver, skin and muscle of Lethrinus lentjan fish species in relation to body length and sex. Sci Total Environ 256:87-94 doi:10.1016/s00489697(99)00363-0

Allen P (1994) Accumulation profiles of lead and the influence of cadmium and mercury in Oreochromis aureus (Steindachner) during chronic exposure. Toxicol Environ Chem 44:101-112 doi: $10.1080 / 02772249409358048$

Amundsen P-A, Knudsen R (2009) Winter ecology of Arctic charr (Salvelinus alpinus) and Brown trout (Salmo trutta) in a subarctic lake, Norway. Aquat Ecol 43:765-775 doi:10.1007/s10452-009-9261-8

Asante KA et al. (2008) Trace elements and stable isotopes $\left(\delta^{13} \mathrm{C}\right.$ and $\left.\delta^{15} \mathrm{~N}\right)$ in shallow and deep-water organisms from the East China Sea. Environ Pollut 156:862-873 doi:10.1016/j.envpol.2008.05.020

Atwell L, Hobson KA, Welch HE (1998) Biomagnification and bioaccumulation of mercury in an arctic marine food web: insights from stable nitrogen isotope analysis. Can J Fish Aquat Sci 55:1114-1121 doi:10.1139/cjfas-55-5-1114

Audet D, Couture P (2003) Seasonal variations in tissue metabolic capacities of yellow perch (Perca flavescens) from clean and metal-contaminated environments. Can J Fish Aquat Sci 60:269-278 doi:10.1139/F03-020

Bearhop S, Thompson DR, Waldron S, Russell IC, Alexander G, Furness RW (1999) Stable isotopes indicate the extent of freshwater feeding by cormorants Phalacrocorax carbo shot at inland fisheries in England. J Appl Ecol 36:75-84 doi:10.1046/j.1365-2664.1999.00378.x

Blanchet C, Rochette L (2008) Nutrition and food consumption among the Inuit of Nunavik. Nunavik Inuit health survey 2004, Qanuippitaa? How are we? Institut national de santé publique du Québec (INSPQ) \& Nunavik Regional Board of Health and Social Services (NRBHSS), Québec, Québec, Canada

Boivin TG, Power G (1990) Winter condition and proximate composition of anadromous Arctic Charr (Salvelinus alpinus) in Eastern Ungava Bay, Québec. Can J Zool 68:2284-2289 doi:10.1139/z90-319

Borrell A, Tornero V, Bhattacharjee D, Aguilar A (2016) Trace element accumulation and trophic relationships in aquatic organisms of the Sundarbans mangrove ecosystem (Bangladesh). Sci Total Environ 545-546:414423 doi:10.1016/j.scitotenv.2015.12.046

Bradley RW, Morris JR (1986) Heavy-metals in fish from a series of metal-contaminated lakes near Sudbury, Ontario. Water Air Soil Poll 27:341-354 doi:10.1007/Bf00649416

Bungala SO, Machiwa JF, Shilla DA (2017) Concentration and biomagnification of heavy metals in biota of the coastal marine areas of Tanzania. J Environ Sci Eng 6:406-424

Burnham KP, Anderson DR (2003) Model selection and multimodel inference: a practical information-theoretic approach. $2^{\text {nd }}$ edn. Springer-Verlag, New York, NY, USA

Bury NR, Walker PA, Glover CN (2003) Nutritive metal uptake in teleost fish. J Exp Biol 206:11-23 doi: $10.1242 /$ jeb.00068

Cabana G, Rasmussen JB (1994) Modeling food-chain structure and contaminant bioaccumulation using stable nitrogen isotopes. Nature 372:255-257 doi:10.1038/372255a0

Campana S, Chouinard G, Hanson J, Frechet A, Brattey J (2000) Otolith elemental fingerprints as biological tracers of fish stocks. Fish Res 46:343-357 doi:10.1016/S0165-7836(00)00158-2

Campbell LM, Norstrom RJ, Hobson KA, Muir DCG, Backus S, Fisk AT (2005) Mercury and other trace elements in a pelagic Arctic marine food web (Northwater Polynya, Baffin Bay). Sci Total Environ 351-352:247-263 doi:10.1016/j.scitotenv.2005.02.043

Canadian Ice Service (2018) Ice archive - daily ice charts - black and white (1999 - 2018) for the Hudson Bay region. Government of Canada. http://climate.weather.gc.ca/climate_data/daily_data_e.html?StationID=52378\&Year=2016\&Month=8\#. Accessed December 82017

Canli M, Atli G (2003) The relationships between heavy metal (Cd, Cr, Cu, Fe, Pb, $\mathrm{Zn}$ ) levels and the size of six Mediterranean fish species. Environ Pollut 121:129-136 doi:10.1016/S0269-7491(02)00194-X

Canli M, Ay Ö, Kalay M (1998) Levels of heavy metals (Cd, $\mathrm{Pb}, \mathrm{Cu}, \mathrm{Cr}$ and $\mathrm{Ni}$ ) in tissue of Cyprinus carpio, Barbus capito and Chondrostoma regium from the Seyhan River, Turkey. Turk J Zool 22:149-158 
Cardwell RD, DeForest DK, Brix KV, Adams WJ (2013) Do Cd, Cu, Ni, Pb, and Zn biomagnify in aquatic ecosystems? Rev Environ Contam T 226:101-122

Chapman GA (1978) Toxicities of cadmium, copper, and zinc to four juvenile stages of Chinook salmon and Steelhead. T Am Fish Soc 107:841-847

Chilton DE, Beamish RJ (1982) Age determination methods for fishes studied by the groundfish program at the Pacific Biological Station. Can J Fish Aquat Sci 60:1-102

Christoffersen KS, Jeppesen E, Moorhead DL, Tranvik LJ (2008) Food-web relationships and community structures in high-latitude lakes. In: Vincent WF, Laybourn-Parr J (eds) Polar lakes and rivers: limnology of Arctic and Antarctic aquatic ecosystems. Oxford University Press, Oxford, United Kingdom, pp 269-289

Cizdziel J, Hinners T, Cross C, Pollard J (2003) Distribution of mercury in the tissues of five species of freshwater fish from Lake Mead, USA. J Environ Monitor 5:802-807 doi:10.1039/b307641p

Cizdziel J, Hinners T, Pollard J, Heithmar E, Cross C (2002) Mercury concentrations in fish from Lake Mead, USA, related to fish size, condition, trophic level, location, and consumption risk. Arch Environ Con Tox 43:309317 doi:10.1007/s00244-002-1191-6

Cook RD (1977) Detection of influential observation in linear regression. Technometrics 19:15-18 doi: $10.2307 / 1268249$

Cossa D et al. (2011) Mercury in the Southern ocean. Geochim Cosmochim Ac 75:4037-4052 doi:10.1016/j.gca.2011.05.001

Craig H (1957) Isotopic standards for carbon and oxygen and correction factors for mass spectrometric analysis of carbon dioxide. Geochim Cosmochim Ac 12:133-149

Croteau MN, Luoma SN, Stewart AR (2005) Trophic transfer of metals along freshwater food webs: Evidence of cadmium biomagnification in nature. Limnol Oceanogr 50:1511-1519 doi:10.4319/lo.2005.50.5.1511

Cullen WR, Reimer KJ (1989) Arsenic speciation in the environment. Chem Rev 89:713-764 doi:10.1021/cr00094a002

Dallinger R, Egg M, Kock G, Hofer R (1997) The role of metallothionein in cadmium accumulation of Arctic char (Salvelinus alpinus) from high alpine lakes. Aquat Toxicol 38:47-66 doi:10.1016/S0166-445x(96)00840-5

Dang F, Wang W-X (2009) Assessment of tissue-specific accumulation and effects of cadmium in a marine fish fed contaminated commercially produced diet. Aquat Toxicol 95:248-255 doi:10.1016/j.aquatox.2009.09.013

De Wet L, Schoonbee H, De Wet L, Wiid A (1994) Bioaccumulation of metals by the Southern mouthbrooder, Pseudocrenilabrus philander (Weber, 1897) from a mine-polluted impoundment. Water SA 20:119-126

DeNiro MJ, Epstein S (1981) Influence of diet on the distribution of nitrogen isotopes in animals. Geochim Cosmochim Ac 45:341-351 doi:10.1016/0016-7037(81)90244-1

Dittman JA, Driscoll CT (2009) Factors influencing changes in mercury concentrations in lake water and yellow perch (Perca flavescens) in Adirondack lakes. Biogeochemistry 93:179-196 doi:10.1007/s10533-009-92899

Douben PE (1989) Uptake and elimination of waterborne cadmium by the fish Noemacheilus Barbatulus L. (Stone Loach). Arch Environ Con Tox 18:576-586 doi:10.1007/Bf01055025

Doucett RR, Hooper W, Power G (1999) Identification of anadromous and nonanadromous adult Brook trout and their progeny in the Tabusintac River, New Brunswick, by means of multiple stable isotope analysis. T Am Fish Soc 128:278-288 doi:10.1577/1548-8659(1999)128<0278:Ioaana>2.0.Co;2

Dutil J (1986) Energetic constraints and spawning interval in the anadromous Arctic charr (Salvelinus alpinus). Copeia 1986:945-955 doi:10.2307/1445291

Eastwood S, Couture P (2002) Seasonal variations in condition and liver metal concentrations of yellow perch (Perca flavescens) from a metal-contaminated environment. Aquat Toxicol 58:43-56 doi:10.1016/s0166445x(01)00218-1

Eisler R (1987) Mercury hazards to fish, wildlife, and invertebrates: a synoptic review. Laurel, MD, USA

Environment Canada (2018a) Daily data report for August 2016, Salluit, Québec. Government of Canada. http://climate.weather.gc.ca/climate_data/daily_data_e.html?StationID=52378\&Year=2016\&Month=8\#. Accessed February 82019

Environment Canada (2018b) Daily data report for February 2016, Salluit, Québec. Government of Canada. http://climate.weather.gc.ca/climate_data/daily_data_e.html?StationID=52378\&timeframe=2\&StartYear=1 840\&EndYear=2017\&Day=29\&Year=2016\&Month=2\#. Accessed February 82019 
Evans MS, Muir DCG, Lockhart WL, Stern G, Ryan M, Roach P (2005) Persistent organic pollutants and metals in the freshwater biota of the Canadian Subarctic and Arctic: an overview. Sci Total Environ 351-352:94-147 doi:10.1016/j.scitotenv.2005.01.052

FAO of the United Nations (2003) Heavy Metals Regulations Legal Notice No 66/2003. FAO, Rome, Italy

Farkas A, Salánki J, Specziár A (2003) Age- and size-specific patterns of heavy metals in the organs of freshwater fish Abramis brama L. populating a low-contaminated site. Water Res 37:959-964 doi:10.1016/s00431354(02)00447-5

Fernandes C, Fontainhas-Fernandes A, Peixoto F, Salgado MA (2007) Bioaccumulation of heavy metals in Liza saliens from the Esmoriz Paramos coastal lagoon, Portugal. Ecotox Environ Safe 66:426-431 doi:10.1016/j.ecoenv.2006.02.007

Fry B, Sherr EB (1989) $\delta^{13} \mathrm{C}$ measurements as indicators of carbon flow in marine and freshwater ecosystems. In: Stable isotopes in ecological research. Springer, New York, NY, USA, pp 196-229

Gantner N et al. (2009) Temporal trends of mercury, cesium, potassium, selenium, and thallium in Arctic char (Salvelinus alpinus) from Lake Hazen, Nunavut, Canada: effects of trophic position, size, and age. Environ Toxicol Chem 28:254-263 doi:10.1897/08-054.1

Ghosh D, Bhattacharya S, Mazumder S (2006) Perturbations in the catfish immune responses by arsenic: organ and cell specific effects. Comp Biochem Phys B 143:455-463 doi:10.1016/j.cbpc.2006.04.010

Glover CN, Hogstrand C (2002) In vivo characterisation of intestinal zinc uptake in freshwater rainbow trout. J Exp Biol 205:141-150

Greenfield BK, Hrabik TR, Harvey CJ, Carpenter SR (2001) Predicting mercury levels in yellow perch: use of water chemistry, trophic ecology, and spatial traits. Can J Fish Aquat Sci 58:1419-1429 doi:10.1139/cjfas-58-71419

Grey J (2001) Ontogeny and dietary specialization in brown trout (Salmo trutta L.) from Loch Ness, Scotland, examined using stable isotopes of carbon and nitrogen. Ecol Freshw Fish 10:168-176 doi:10.1034/j.16000633.2001.100306.x

Grosell M, Blanchard J, Brix KV, Gerdes R (2007) Physiology is pivotal for interactions between salinity and acute copper toxicity to fish and invertebrates. Aquat Toxicol 84:162-172 doi:10.1016/j.aquatox.2007.03.026

Handy RD Dietary exposure to toxic metals in fish. In: Taylor E (ed) Society for Experimental Biology Seminar Series, Cambridge, United Kingdom, 1996. Cambridge University Press, pp 29-60

Health Canada (2018) Health Canada's maximum levels for chemical contaminants in foods. Government of Canada Accessed Febuary 1st 2018

Hecky R, Hesslein RH (1995) Contributions of benthic algae to lake food webs as revealed by stable isotope analysis. J N Am Benthol Soc 14:631-653 doi:10.2307/1467546

Herbinger C, Friars G (1991) Correlation between condition factor and total lipid content in Atlantic salmon, Salmo salar L., parr. Aquac Res 22:527-529

Hesslein RH, Hallard K, Ramlal P (1993) Replacement of sulfur, carbon, and nitrogen in tissue of growing Broad whitefish (Coregonus nasus) in response to a change in diet traced by $\delta^{34} \mathrm{~S}, \delta^{13} \mathrm{C}$, and $\delta^{15} \mathrm{~N}$. Can J Fish Aquat Sci 50:2071-2076

Huet C, Rosol R, Egeland GM (2012) The prevalence of food insecurity is high and the diet quality poor in Inuit communities. J Nutr 142:541-547 doi:10.3945/jn.111.149278

Ikemoto T et al. (2008) Biomagnification of trace elements in the aquatic food web in the Mekong Delta, South Vietnam using stable carbon and nitrogen isotope analysis. Arch Environ Con Tox 54:504-515 doi:10.1007/s00244-007-9058-5

Jara-Marini ME, Soto-Jimenez MF, Paez-Osuna F (2009) Trophic relationships and transference of cadmium, copper, lead and zinc in a subtropical coastal lagoon food web from SE Gulf of California. Chemosphere 77:1366-1373 doi:10.1016/j.chemosphere.2009.09.025

Jardine TD, Hunt RJ, Pusey BJ, Bunn SE (2011) A non-lethal sampling method for stable carbon and nitrogen isotope studies of tropical fishes. Mar Freshw Res 62:83-90 doi:10.1071/Mf10211

Jobling M (1981) The influences of feeding on the metabolic rate of fishes - a short review. J Fish Biol 18:385-400 doi:10.1111/j.1095-8649.1981.tb03780.x

Jørgensen E, Johansen S, Jobling M (1997) Seasonal patterns of growth, lipid deposition and lipid depletion in anadromous Arctic charr. J Fish Biol 51:312-326 
Kahilainen K et al. (2016) Seasonal dietary shift to zooplankton influences stable isotope ratios and total mercury concentrations in Arctic charr (Salvelinus alpinus (L.)). Hydrobiologia 783:47-63 doi:10.1007/s10750-0162685-y

Kainz MJ, Fisk AT (2009) Integrating lipids and contaminants in aquatic ecology and ecotoxicology. In: Kainz MJ, Brett MT, Arts MT (eds) Lipids in Aquatic Ecosystems. Springer, New York, New York, USA, pp 93-114

Kalay M, Canli M (2000) Elimination of essential $(\mathrm{Cu}, \mathrm{Zn})$ and non-essential $(\mathrm{Cd}, \mathrm{Pb})$ metals from tissues of a freshwater fish Tilapia zilli. Turk J Zool 24:429-436

Kamunde C, Grosell M, Higgs D, Wood CM (2002) Copper metabolism in actively growing Rainbow trout (Oncorhynchus mykiss): interactions between dietary and waterborne copper uptake. J Exp Biol 205:279290

Karthikeyan S, Palaniappan P, Sabhanayakam S (2007) Influence of pH and water hardness upon nickel accumulation in edible fish Cirrhinus mrigala. J Environ Biol 28:489

Keva O, Hayden B, Harrod C, Kahilainen K (2017) Total mercury concentrations in liver and muscle of European whitefish (Coregonus lavaretus (L.)) in a subarctic lake - Assessing the factors driving year-round variation. Environ Pollut 231:1518-1528 doi:10.1016/j.envpol.2017.09.012

Kidd K, Hesslein R, Fudge R, Hallard K (1995) The influence of trophic level as measured by $\delta^{15} \mathrm{~N}$ on mercury concentrations in freshwater organisms. In: Mercury as a global pollutant. Springer, Dordrecht, Netherlands, pp 1011-1015

Klemetsen A, Knudsen R, Staldvik F, Amundsen P-A (2003) Habitat, diet and food assimilation of Arctic charr under the winter ice in two subarctic lakes. J Fish Biol 62:1082-1098 doi:10.1046/j.10958649.2003.00101.x

Köck G, Triendl M, Hofer R (1996) Seasonal patterns of metal accumulation in Arctic char (Salvelinus alpinus) from an oligotrophic Alpine lake related to temperature. Can J Fish Aquat Sci 53:780-786 doi:10.1139/cjfas-53-4-780

Kojadinovic J, Potier M, Le Corre M, Cosson RP, Bustamante P (2007) Bioaccumulation of trace elements in pelagic fish from the Western Indian Ocean. Environ Pollut 146:548-566 doi:10.1016/j.envpol.2006.07.015

Kraemer LD, Evans D, Dillon PJ (2012) The impacts of ontogenetic dietary shifts in Yellow perch (Perca flavescens) on $\mathrm{Zn}$ and $\mathrm{Hg}$ accumulation. Ecotox Environ Safe 78:246-252 doi:10.1016/j.ecoenv.2011.11.033

Kress N, Herut B, Shefer E, Hornung H (1999) Trace element levels in fish from clean and polluted coastal marine sites in the Mediterranean Sea, Red Sea and North Sea. Helgoland Mar Res 53:163-170 doi: $10.1007 / \mathrm{s} 101520050022$

Kuhnlein HV, Receveur O (2007) Local cultural animal food contributes high levels of nutrients for Arctic Canadian Indigenous adults and children. J Nutr 137:1110-1104 doi:10.1093/jn/137.4.1110

Langston W (2017) Toxic effects of metals and the incidence of metal pollution in marine ecosystems. In: Heavy metals in the marine environment. 1 edn. CRC Press, Boca Raton, FL, USA, pp 101-120. doi:https://doi.org/10.1201/9781351073158

Lee CS-1, Li X, Shi W, Cheung SC-n, Thornton I (2006) Metal contamination in urban, suburban, and country park soils of Hong Kong: a study based on GIS and multivariate statistics. Sci Total Environ 356:45-61 doi:10.1016/j.scitotenv.2005.03.024

Linnebjerg JF et al. (2016) Deciphering the structure of the West Greenland marine food web using stable isotopes $\left(\delta^{13} \mathrm{C}, \delta^{15} \mathrm{~N}\right)$. Mar Biol 163:230 doi:10.1007/s00227-016-3001-0

Logan JM, Jardine TD, Miller TJ, Bunn SE, Cunjak RA, Lutcavage ME (2008) Lipid corrections in carbon and nitrogen stable isotope analyses: comparison of chemical extraction and modelling methods. J Anim Ecol 77:838-846 doi:10.1111/j.1365-2656.2008.01394.x

Lohan MC, Statham PJ, Peck L (2001) Trace metals in the Antarctic soft-shelled clam Laternula elliptica: implications for metal pollution from Antarctic research stations. Polar Biol 24:808-817 doi:10.1007/s003000100279

Loro VL, Jorge MB, da Silva KR, Wood CM (2012) Oxidative stress parameters and antioxidant response to sublethal waterborne zinc in a euryhaline teleost Fundulus heteroclitus: Protective effects of salinity. Aquat Toxicol 110-111:187-193 doi:10.1016/j.aquatox.2012.01.012

Lukacs PM, Burnham KP, Anderson DR (2010) Model selection bias and Freedman's paradox. Ann I Stat Math 62:117-125 
Maes G, Raeymaekers J, Pampoulie C, Seynaeve A, Goemans G, Belpaire C, Volckaert F (2005) The catadromous European eel Anguilla anguilla (L.) as a model for freshwater evolutionary ecotoxicology: Relationship between heavy metal bioaccumulation, condition and genetic variability. Aquat Toxicol 73:99-114 doi:10.1016/j.aquatox.2005.01.010

Mariotti A (1983) Atmospheric nitrogen is a reliable standard for natural $\delta^{15} \mathrm{~N}$ abundance measurements. Nature 303:685

Marmulla G, Rösch R (1990) Maximum daily ration of juvenile fish fed on living natural zooplankton. J Fish Biol 36:789-801 doi:10.1111/j.1095-8649.1990.tb05628.x

Mathews T, Fisher NS (2009) Dominance of dietary intake of metals in marine elasmobranch and teleost fish. Sci Total Environ 407:5156-5161

Mergler D, Anderson HA, Chan LHM, Mahaffey KR, Murray M, Sakamoto M, Stern AH (2007) Methylmercury exposure and health effects in humans: a worldwide concern. Ambio 36:3-11

Minagawa M, Wada E (1984) Stepwise enrichment of $\delta^{15} \mathrm{~N}$ along food chains: further evidence and the relation between $\delta^{15} \mathrm{~N}$ and animal age. Geochim Cosmochim Ac 48:1135-1140

Mishra AK, Mohanty B (2008) Acute toxicity impacts of hexavalent chromium on behavior and histopathology of gill, kidney and liver of the freshwater fish, Channa punctatus (Bloch). Environ Toxicol Phar 26:136-141 doi:10.1016/j.etap.2008.02.010

Murdoch A, Power M (2013) The effect of lake morphometry on thermal habitat use and growth in Arctic charr populations: implications for understanding climate-change impacts. Ecol Freshw Fish 22:453-466

Ney JJ, Van Hassel JH (1983) Sources of variability in accumulation of heavy metals by fishes in a roadside stream. Arch Environ Con Tox 12:701-706

Nichols J, Playle R (2004) Influence of temperature on silver accumulation and depuration in Rainbow trout. J Fish Biol 64:1638-1654 doi:10.1111/j.1095-8649.2004.00422.x

Nordberg M (1998) Metallothioneins: historical review and state of knowledge. Talanta 46:243-254

Odžak N, Zvonaric T (1995) Cadmium and lead uptake from food by the fish Dicentrarchus labrax. Water Sci Technol 32:49-55 doi:10.1016/0273-1223(96)00069-8

Ofukany AFA, Wassenaar LI, Bond AL, Hobson KA (2014) Defining fish community structure in Lake Winnipeg using stable isotopes $\left(\delta^{13} \mathrm{C}, \delta^{15} \mathrm{~N}, \delta^{34} \mathrm{~S}\right)$ : Implications for monitoring ecological responses and trophodynamics of mercury \& other trace elements. Sci Total Environ 497-498:239-249 doi:https://doi.org/10.1016/j.scitotenv.2014.07.125

Pannetier P, Caron A, Campbell PG, Pierron F, Baudrimont M, Couture P (2016) A comparison of metal concentrations in the tissues of yellow American eel (Anguilla rostrata) and European eel (Anguilla anguilla). Sci Total Environ 569-570:1435-1445 doi:10.1016/j.scitotenv.2016.06.232

Peterson BJ, Fry B (1987) Stable isotopes in ecosystem studies. Annu Rev Ecol Syst 18:293-320 doi:10.1146/annurev.es.18.110187.001453

Plum LM, Rink L, Haase H (2010) The essential toxin: impact of zinc on human health. Int J Env Res Pub He 7:1342-1365 doi:10.3390/ijerph7041342

Post DM (2002) Using stable isotopes to estimate trophic position: models, methods, and assumptions. Ecology 83:703-718 doi:10.1890/0012-9658(2002)083[0703:Usitet]2.0.Co;2

Pouil S, Oberhansli F, Bustamante P, Metian M (2017) Dietary Zn and the subsequent organotropism in fish: No influence of food quality, frequency of feeding and environmental conditions ( $\mathrm{pH}$ and temperature). Chemosphere 183:503-509 doi:10.1016/j.chemosphere.2017.05.126

Power M, Klein G, Guiguer K, Kwan M (2002) Mercury accumulation in the fish community of a sub-Arctic lake in relation to trophic position and carbon sources. J Appl Ecol 39:819-830

Pyle GG, Rajotte JW, Couture P (2005) Effects of industrial metals on wild fish populations along a metal contamination gradient. Ecotox Environ Safe 61:287-312

Qu R, Feng M, Wang X, Qin L, Wang C, Wang Z, Wang L (2014) Metal accumulation and oxidative stress biomarkers in liver of freshwater fish Carassius auratus following in vivo exposure to waterborne zinc under different $\mathrm{pH}$ values. Aquat Toxicol 150:9-16 doi:https://doi.org/10.1016/j.aquatox.2014.02.008

Rabinowitz MB (1991) Toxicokinetics of bone lead. Environ Health Persp 91:33-37 doi:10.1289/ehp.919133

Rajotte JW, Couture P (2002) Effects of environmental metal contamination on the condition, swimming performance, and tissue metabolic capacities of wild yellow perch (Perca flavescens). Can J Fish Aquat Sci 59:1296-1304 doi:10.1139/F02-095 
Reynders H, Van Campenhout K, Bervoets L, De Coen WM, Blust R (2006) Dynamics of cadmium accumulation and effects in common carp (Cyprinus carpio) during simultaneous exposure to water and food (Tubifex tubifex). Environ Toxicol Chem 25:1558-1567

Ricker WE (1975) Computation and interpretation of biological statistics of fish populations. B Fish Res Board Can 191:1-382

Rikardsen A, Amundsen P-A, Bodin P (2003) Growth and diet of anadromous Arctic charr after their return to freshwater. Ecol Freshw Fish 12:74-80 doi:10.1034/j.1600-0633.2003.00001.x

Roesijadi G (1994) Metal regulation in aquatic animals: Mechanism of uptake, accumulation and release. Aquat Toxicol 1994:387-420

Roméo M, Siau Y, Sidoumou Zn, Gnassia-Barelli M (1999) Heavy metal distribution in different fish species from the Mauritania coast. Sci Total Environ 232:169-175 doi:10.1016/S0048-9697(99)00099-6

Sanderson BL, Tran CD, Coe HJ, Pelekis V, Steel EA, Reichert WL (2009) Nonlethal sampling of fish caudal fins yields valuable stable isotope data for threatened and endangered fishes. T Am Fish Soc 138:1166-1177 doi:10.1577/T08-086.1

Seyler P, Martin J-M (1991) Arsenic and selenium in a pristine river-estuarine system: the Krka (Yugoslavia). Mar Chem 34:137-151 doi:10.1016/0304-4203(91)90018-R

Shapiro SS, Wilk MB (1965) An analysis of variance test for normality (complete samples). Biometrika 52:591-611

Sharif AKM, Alamgir M, Mustafa AI, Hossain MA, Amin MN (1993) Trace element concentrations in ten species of freshwater fish of Bangladesh. Sci Total Environ 138:117-126 doi:10.1016/0048-9697(93)90409-y

Shears MA, Fletcher GL (1979) The binding of zinc to the soluble proteins of intestinal mucosa in winter flounder (Pseudopleuronectes americanus). Comp Biochem Phys B 64:297-309 doi:https://doi.org/10.1016/03050491(79)90147-0

Smith AH, Steinmaus CM (2009) Health effects of arsenic and chromium in drinking water: recent human findings. Annu Rev Publ Health 30:107-122 doi:10.1146/annurev.publhealth.031308.100143

Solis C, Isaac-Olive K, Mireles A, Vidal-Hernandez M (2009) Determination of trace metals in cow's milk from waste water irrigated areas in Central Mexico by chemical treatment coupled to PIXE. Microchem J 91:912 doi:10.1016/j.microc.2008.06.001

Sörensen EMB (1991) Metal poisoning in fish. CRC Press, Boca Raton, FL, USA

Soto-Jiménez MF, Arellano-Fiore C, Rocha-Velarde R, Jara-Marini ME, Ruelas-Inzunza J, Páez-Osuna F (2011) Trophic Transfer of lead through a model marine four-level food chain: Tetraselmis suecica, Artemia franciscana, Litopenaeus vannamei, and Haemulon scudderi. Environ Contam Toxicol 61:280-291 doi:10.1007/s00244-010-9620-4

Spry DJ, Wood CM (1989) A kinetic method for the measurement of zinc influx in-vivo in the Rainbow trout, and the effects of waterborne calcium on flux rates. J Exp Biol 142:425-446

Squadrone S et al. (2013) Heavy metals distribution in muscle, liver, kidney and gill of European catfish (Silurus glanis) from Italian Rivers. Chemosphere 90:358-365 doi:10.1016/j.chemosphere.2012.07.028

Swanson H, Gantner N, Kidd K, Muir DCG, Reist J (2011) Comparison of mercury concentrations in landlocked, resident, and sea-run fish (Salvelinus spp.) from Nunavut, Canada. Environ Toxicol Chem 30:1459-1467 doi:10.1002/etc.517

Swanson HK, Kidd KA (2010) Mercury concentrations in Arctic food fishes reflect the presence of anadromous Arctic charr (Salvelinus alpinus), species, and life history. Environ Sci Technol 44:3286-3292 doi:10.1021/es100439t

Symonds MR, Moussalli A (2011) A brief guide to model selection, multimodel inference and model averaging in behavioural ecology using Akaike's information criterion. Behav Ecol Sociobiol 65:13-21

Tam N, Yao M (1998) Normalisation and heavy metal contamination in mangrove sediments. Sci Total Environ 216:33-39 doi:10.1016/S0048-9697(98)00132-6

Thompson JM, Bergersen EP, Carlson CA, Kaeding LR (1991) Role of size, condition, and lipid content in the overwinter survival of age -0 Colorado squawfish. T Am Fish Soc 120:346-353

Tulasi SJ, Reddy PUM, Rao JVR (1992) Accumulation of lead and effects on total lipids and lipid derivatives in the freshwater fish Anabas testudineus (Bloch). Ecotox Environ Safe 23:33-38 doi:https://doi.org/10.1016/0147-6513(92)90019-Y

Van der Velden S, Dempson J, Power M (2015) Comparing mercury concentrations across a thirty year time span in anadromous and non-anadromous Arctic charr from Labrador, Canada. Sci Total Environ 509:165-174 
van der Velden S, Dempson JB, Evans MS, Muir DCG, Power M (2013a) Basal mercury concentrations and biomagnification rates in freshwater and marine food webs: Effects on Arctic charr (Salvelinus alpinus) from eastern Canada. Sci Total Environ 444:531-542 doi:10.1016/j.scitotenv.2012.11.099

van der Velden S, Evans MS, Dempson JB, Muir DCG, Power M (2013b) Comparative analysis of total mercury concentrations in anadromous and non-anadromous Arctic charr (Salvelinus alpinus) from eastern Canada. Sci Total Environ 447:438-449 doi:https://doi.org/10.1016/j.scitotenv.2012.12.092

Van Leeuwen TE, Rosenfeld JS, Richards JG (2012) Effects of food ration on SMR: influence of food consumption on individual variation in metabolic rate in juvenile Coho salmon (Onchorhynchus kisutch). J Anim Ecol 81:395-402 doi:10.1111/j.1365-2656.2011.01924.x

Vander Zanden MJ, Hulshof M, Ridgway MS, Rasmussen JB (1998) Application of stable isotope techniques to trophic studies of age-0 Smallmouth bass. T Am Fish Soc 127:729-739 doi:10.1577/15488659(1998)127<0729:AOSITT>2.0.CO;2

Vander Zanden MJ, Rasmussen JB (2001) Variation in $\delta^{15} \mathrm{~N}$ and $\delta^{13} \mathrm{C}$ trophic fractionation. Limnol Oceanogr 46:2061-2066 doi:10.4319/lo.2001.46.8.2061

Vicente-Martorell JJ, Galindo-Riaño MD, García-Vargas M, Granado-Castro MD (2009) Bioavailability of heavy metals monitoring water, sediments and fish species from a polluted estuary. J Hazard Mater 162:823-836 doi:https://doi.org/10.1016/j.jhazmat.2008.05.106

Wagner A, Boman J (2003) Biomonitoring of trace elements in muscle and liver tissue of freshwater fish. Apectrochim Acta B 58:2215-2226 doi:10.1016/j.sab.2003.05.003

Wiener JG, Krabbenhoft DP, Heinz GH, Scheuhammer AM (2003) Ecotoxicology of mercury. In: Hoffman DJ, A. RB, Jr. BGA, Jr. CJ (eds) Handbook of ecotoxicology. $2^{\text {nd }}$ edn. CRC Press, Boca Raton, FL, USA, pp 409463

Yang R, Brauner C, Thurston V, Neuman J, Randall DJ (2000) Relationship between toxicant transfer kinetic processes and fish oxygen consumption. Aquat Toxicol 48:95-108. doi:10.1016/S0166-445x(99)00050-8

Yi Y-J, Zhang S-H (2012) Heavy metal (Cd, Cr, Cu, Hg, Pb, Zn) concentrations in seven fish species in relation to fish size and location along the Yangtze River. Environ Sci Pollut R 19:3989-3996

Yilmaz AB, Sangün MK, Yağlığlu D, Turan C (2010) Metals (major, essential to non-essential) composition of the different tissues of three demersal fish species from İskenderun Bay, Turkey. Food Chem 123:410-415 doi:10.1016/j.foodchem.2010.04.057

Zar JH (2007) Biostatistical analysis. $5^{\text {th }}$ edn. Prentice Hall, Inc., Upper Saddle River, NJ, USA

Zhang L, Wang W-X (2007) Waterborne cadmium and zinc uptake in a euryhaline teleost Acanthopagrus schlegeli acclimated to different salinities. Aquat Toxicol 84:173-181 doi:10.1016/j.aquatox.2007.03.027

Zhao LQ, Yang F, Yan XW (2013) Biomagnification of trace elements in a benthic food web: the case study of Deer Island (Northern Yellow Sea). Chem Ecol 29:197-207 doi:10.1080/02757540.2012.753062 


\section{Tables and Figure Captions}

Table 1 Summary data for anadromous Arctic charr captured during both collection periods (summer 2016 and post-winter 2017). Mean \pm standard deviation and range (minimums and maximums) are given for fork length, somatic condition values $(\mathrm{K})$, age, and dorsal muscle stable isotopes $\left(\delta^{13} \mathrm{C}\right.$ and $\left.\delta^{15} \mathrm{~N}\right)$. Significant seasonal variation is denoted with $*(\mathrm{p}<0.05), * *(p<0.001)$, and $* * *(p<0.0001)$

\begin{tabular}{|c|c|c|c|c|c|c|}
\hline Season & $N$ & Fork length $(\mathrm{mm})$ & Age (Years) & $\mathrm{K}$ & $\delta^{13} \mathrm{C}(\%)$ & $\delta^{15} \mathrm{~N}(\%)$ \\
\hline Summer 2016 & 30 & $\begin{array}{l}487.3 \pm 87.4 \\
311.0 ; 653.0\end{array}$ & $\begin{array}{c}9.50 \pm 2.39 \\
5 ; 15\end{array}$ & $\begin{array}{c}1.05 \pm 0.02 * * * \\
0.57 ; 1.69\end{array}$ & $\begin{array}{c}-19.48 \pm 0.89 * * * \\
-21.64 ;-17.39\end{array}$ & $\begin{array}{l}13.05 \pm 0.83 \\
10.76 ; 15.00\end{array}$ \\
\hline Post-Winter 2017 & 29 & $\begin{array}{c}452.6 \pm 139.6 \\
221.0 ; 698.5\end{array}$ & $\begin{array}{c}8.97 \pm 2.65 \\
4 ; 16\end{array}$ & $\begin{array}{c}0.90 \pm 0.10 \\
0.51 ; 1.02\end{array}$ & $\begin{array}{l}-20.70 \pm 1.11 \\
-22.89 ;-16.85\end{array}$ & $\begin{array}{l}13.22 \pm 1.13 \\
10.94 ; 15.04\end{array}$ \\
\hline
\end{tabular}

871

, 2 Mean \pm standard deviation and range (minimums and maximums) of dorsal muscle (top) and liver (bottom) concentrations (dry weight) of As, Cd, Cr, $\mathrm{Cu}, \mathrm{Ni}, \mathrm{Pb}$ and $\mathrm{Zn}$ from anadromous Arctic charr captured during summer 2016 and post-winter 2017 samplings. For a common tissue type, significant seasonal differences are denoted as: $*(\mathrm{p}<0.05),{ }^{* *}(p<0.001)$, and $* * *(p<0.0001)$. Within a season, significant differences between tissues are denoted with: ${ }^{1}(\mathrm{p}<$ $0.05),{ }^{2}(p<0.001)$, and ${ }^{3}(p<0.0001)$.

\begin{tabular}{|c|c|c|c|c|c|c|c|}
\hline Season & As $\left(\mathrm{mg} \cdot \mathrm{kg}^{-1}\right)$ & $\mathrm{Cd}\left(\mathrm{mg} \cdot \mathrm{kg}^{-1}\right)$ & $\mathrm{Cr}\left(\mathrm{mg} \cdot \mathrm{kg}^{-1}\right)$ & $\mathrm{Cu}\left(\mathrm{mg} \cdot \mathrm{kg}^{-1}\right)$ & $\mathrm{Ni}\left(\mathrm{mg} \cdot \mathrm{kg}^{-1}\right)$ & $\mathrm{Pb}\left(\mathrm{mg} \cdot \mathrm{kg}^{-1}\right)$ & $\mathrm{Zn}\left(\mathrm{mg} \cdot \mathrm{kg}^{-1}\right)$ \\
\hline Summer 2016 & $1.93 \pm 0.60$ & $0.03 \pm 0.03 * * *$ & $0.26 \pm 0.06$ & $1.79 \pm 0.48$ & $0.09 \pm 0.06$ & $0.05 \pm 0.07$ & $22.77 \pm 4.40$ \\
\hline Dorsal Muscle & $0.83 ; 3.34$ & $0.00 ; 0.16$ & $0.21 ; 0.55$ & $1.09 ; 3.72$ & $0.02 ; 0.35$ & $0.00 ; 0.28$ & $16.67 ; 39.76$ \\
\hline Post-Winter 2017 & $1.96 \pm 0.76$ & $0.01 \pm 0.01$ & $0.46 \pm 0.11 * * * 3$ & $1.71 \pm 0.72$ & $0.15 \pm 0.07 * * *$ & $0.05 \pm 0.03 *$ & $28.12 \pm 13.96^{*}$ \\
\hline Dorsal Muscle & $0.09 ; 3.02$ & $0.00 ; 0.04$ & $0.36 ; 0.84$ & $1.00 ; 4.48$ & $0.08 ; 0.35$ & $0.02 ; 0.17$ & $15.87 ; 85.63$ \\
\hline Summer 2016 & $2.3 \pm 0.75^{* 1}$ & $0.52 \pm 0.41^{3}$ & $0.26 \pm 0.04$ & $21.26 \pm 64.70^{3}$ & $0.23 \pm 0.14^{3}$ & $0.03 \pm 0.02$ & $115.68 \pm 28.00^{3}$ \\
\hline Liver & $1.22 ; 3.83$ & $0.17 ; 2.01$ & $0.20 ; 0.38$ & $6.10 ; 343.75$ & $0.05 ; 0.71$ & $0.01 ; 0.12$ & $70.02 ; 172.90$ \\
\hline Post-Winter 2017 & $1.68 \pm 0.91$ & $1.00 \pm 0.76^{* * * 3}$ & $0.37 \pm 0.05^{* * *}$ & $72.22 \pm 42.65^{* 3}$ & $0.19 \pm 0.06^{1}$ & $0.05 \pm 0.02 * * *$ & $119.14 \pm 33.94^{3}$ \\
\hline Liver & $0.08 ; 3.63$ & $0.30 ; 4.24$ & $0.30 ; 0.51$ & $25.39 ; 203.99$ & $0.08 ; 0.41$ & $0.03 ; 0.10$ & $48.15 ; 190.14$ \\
\hline
\end{tabular}


Table 3 The relative importance of individual parameters and interaction terms included in the models determined using AICc model selection that best described anadromous Deception River Arctic charr dorsal muscle and liver concentrations of essential $(\mathrm{Cu}$ and $\mathrm{Zn})$ (left) and non-essential metals $(\mathrm{As}, \mathrm{Cd}, \mathrm{Cr}, \mathrm{Ni}$, and $\mathrm{Pb})$

\begin{tabular}{|c|c|c|c|c|c|c|c|c|c|c|c|c|c|c|}
\hline & \multicolumn{2}{|c|}{$\mathrm{Cu}\left(\mathrm{mg} \cdot \mathrm{kg}^{-1}\right)$} & \multicolumn{2}{|c|}{$\mathrm{Zn}\left(\mathrm{mg} \cdot \mathrm{kg}^{-1}\right)$} & \multicolumn{2}{|c|}{ As $\left(\mathrm{mg} \cdot \mathrm{kg}^{-1}\right)$} & \multicolumn{2}{|c|}{$\mathrm{Cd}\left(\mathrm{mg} \cdot \mathrm{kg}^{-1}\right)$} & \multicolumn{2}{|c|}{$\mathrm{Cr}\left(\mathrm{mg} \cdot \mathrm{kg}^{-1}\right)$} & \multicolumn{2}{|c|}{$\mathrm{Ni}\left(\mathrm{mg} \cdot \mathrm{kg}^{-1}\right)$} & \multicolumn{2}{|c|}{$\mathrm{Pb}\left(\mathrm{mg} \cdot \mathrm{kg}^{-1}\right)$} \\
\hline & $\begin{array}{l}\text { Dorsal } \\
\text { Muscle }\end{array}$ & Liver & $\begin{array}{c}\text { Dorsal } \\
\text { Muscle }\end{array}$ & Liver & $\begin{array}{l}\text { Dorsal } \\
\text { Muscle }\end{array}$ & Liver & $\begin{array}{l}\text { Dorsal } \\
\text { Muscle }\end{array}$ & Liver & $\begin{array}{c}\text { Dorsal } \\
\text { Muscle }\end{array}$ & Liver & $\begin{array}{l}\text { Dorsal } \\
\text { Muscle }\end{array}$ & Liver & $\begin{array}{l}\text { Dorsal } \\
\text { Muscle }\end{array}$ & Liver \\
\hline Season & 0.48 & 0.99 & 0.15 & 0.24 & 0.89 & 1.00 & 1.00 & 0.73 & 1.00 & 1.00 & 1.00 & 1.00 & 0.28 & 1.00 \\
\hline Fork length & 0.11 & 0.31 & 0.99 & 0.99 & 0.18 & - & 0.36 & 0.63 & - & - & 0.28 & - & - & - \\
\hline Age & - & - & - & - & 0.54 & 1.00 & 0.18 & 0.37 & - & - & 0.18 & 1.00 & 1.00 & - \\
\hline Somatic Condition & 0.25 & 0.51 & 0.69 & 0.99 & 1.00 & 0.09 & 1.00 & 1.00 & - & 0.86 & 0.12 & 1.00 & 1.00 & 1.00 \\
\hline$\delta^{13} \mathrm{C}$ & 0.21 & 0.99 & 0.67 & 0.99 & 1.00 & 0.63 & - & - & 1.00 & 0.43 & - & - & 1.00 & 0.16 \\
\hline$\delta^{15} \mathrm{~N}$ & 0.23 & 0.68 & - & 0.75 & 0.83 & 0.52 & 1.00 & 1.00 & 0.32 & 0.27 & 0.26 & - & 1.00 & 0.22 \\
\hline Season*Condition & - & 0.51 & 0.15 & - & 0.64 & - & - & - & - & 0.13 & - & 0.35 & - & 0.22 \\
\hline Season $* \delta^{13} \mathrm{C}$ & 0.09 & 0.99 & - & - & 0.24 & - & - & - & - & - & - & - & - & - \\
\hline Fork length $* \delta^{15} \mathrm{~N}$ & - & - & - & 0.51 & - & - & - & 0.63 & - & - & - & - & - & - \\
\hline Age $* \delta^{15} \mathrm{~N}$ & - & - & - & - & - & 0.20 & - & 0.37 & - & - & - & - & 1.00 & - \\
\hline Condition* $\delta^{15} \mathrm{~N}$ & - & - & - & - & 0.67 & - & 1.00 & 0.54 & - & - & - & - & 1.00 & 0.22 \\
\hline
\end{tabular}


Table 4 Summary of the composite models (parameter and interaction term estimates $(\widetilde{\bar{B}})$, unconditional standard errors $(\hat{s} e(\widetilde{\bar{B}})$ ), and upper (UCI) and lower (LCI) $95 \%$ confidence intervals), determined through model averaging, that best describe dorsal muscle concentrations of essential $(\mathrm{Cu}$ and $\mathrm{Zn})$ and non-essential metals ( $\mathrm{As}, \mathrm{Cd}, \mathrm{Cr}, \mathrm{Cu}$, $\mathrm{Ni}$, and $\mathrm{Pb}$ )

\begin{tabular}{|c|c|c|c|c|c|}
\hline Element & Parameter & $\widetilde{\bar{B}}$ & $\hat{\hat{s} e}(\widetilde{\bar{B}})$ & $\overline{\mathrm{UCI}}$ & LCI \\
\hline \multirow[t]{7}{*}{$\mathrm{Cu}\left(\mathrm{mg} \cdot \mathrm{kg}^{-1}\right)$} & Intercept & 0.300 & 0.168 & 0.637 & -0.037 \\
\hline & Season & -0.009 & 0.014 & 0.019 & -0.036 \\
\hline & Fork length & $7.889 \times 10^{-7}$ & $1.353 \times 10^{-5}$ & $2.790 \times 10^{-5}$ & $-2.600 \times 10^{-5}$ \\
\hline & Condition & -0.019 & 0.043 & 0.067 & -0.106 \\
\hline & $\delta^{13} \mathrm{C}$ & 0.001 & 0.004 & 0.009 & -0.007 \\
\hline & $\delta^{15} \mathrm{~N}$ & -0.003 & 0.007 & 0.011 & -0.017 \\
\hline & Season $* \delta^{13} \mathrm{C}$ & -0.002 & 0.005 & 0.007 & -0.012 \\
\hline \multirow[t]{6}{*}{$\mathrm{Zn}\left(\mathrm{mg} \cdot \mathrm{kg}^{-1}\right)$} & Intercept & 1.374 & 0.380 & 2.134 & 0.614 \\
\hline & Season & 0.001 & 0.004 & 0.008 & -0.006 \\
\hline & Fork length & $-4.704 \times 10^{-3}$ & $1.211 \times 10^{-3}$ & $-2.300 \times 10^{-3}$ & $-7.100 \times 10^{-3}$ \\
\hline & Condition & -0.118 & 0.111 & 0.104 & -0.340 \\
\hline & $\delta^{13} \mathrm{C}$ & -0.017 & 0.015 & -0.016 & -0.017 \\
\hline & Season*Condition & -0.073 & 0.087 & 0.102 & -0.248 \\
\hline \multirow[t]{10}{*}{ As $\left(\mathrm{mg} \cdot \mathrm{kg}^{-1}\right)$} & Intercept & -5.384 & 2.170 & -1.041 & -9.727 \\
\hline & Season & -0.127 & 0.157 & 0.187 & -0.441 \\
\hline & Fork length & $-3.332 \times 10^{-3}$ & $5.875 \times 10^{-3}$ & $1.509 \times 10^{-2}$ & $-8.400 \times 10^{-3}$ \\
\hline & Age & 0.026 & 0.037 & 0.101 & -0.049 \\
\hline & Condition & 0.253 & 0.921 & 2.095 & -1.589 \\
\hline & $\delta^{13} \mathrm{C}$ & -0.226 & 0.081 & -0.065 & -0.388 \\
\hline & $\delta^{15} \mathrm{~N}$ & 0.172 & 0.127 & 0.426 & -0.082 \\
\hline & Season*Condition & 1.106 & 1.045 & 3.198 & -0.985 \\
\hline & Season $* \delta^{13} \mathrm{C}$ & 1.028 & 2.7.459 & 10.486 & -10.486 \\
\hline & Condition $* \delta^{15} \mathrm{~N}$ & -0.742 & 0.652 & 2.104 & -1.126 \\
\hline \multirow[t]{3}{*}{$\mathrm{Cd}\left(\mathrm{mg} \cdot \mathrm{kg}^{-1}\right)$} & Intercept & -1.185 & 0.749 & 0.314 & -2.685 \\
\hline & Season & -0.302 & 0.041 & -0.221 & -0.384 \\
\hline & Fork length & $-2.168 \times 10^{-3}$ & $3.494 \times 10^{-3}$ & $9.160 \times 10^{-3}$ & $-4.800 \times 10^{-3}$ \\
\hline
\end{tabular}




\begin{tabular}{|c|c|c|c|c|c|}
\hline & $\overline{\text { Age }}$ & $-3.952 \times 10^{-3}$ & $1.814 \times 10^{-3}$ & $7.705 \times 10^{-2}$ & $-6.910 \times 10^{-2}$ \\
\hline & Condition & -0.207 & 0.242 & 0.278 & -0.692 \\
\hline & $\delta^{15} \mathrm{~N}$ & -0.030 & 0.054 & 0.077 & -0.137 \\
\hline & Condition $* \delta^{15} \mathrm{~N}$ & 0.537 & 0.188 & 0.914 & 0.160 \\
\hline \multirow[t]{4}{*}{$\mathrm{Cr}\left(\mathrm{mg} \cdot \mathrm{kg}^{-1}\right)$} & Intercept & -0.861 & 0.242 & -0.376 & -1.345 \\
\hline & Season & 0.108 & 0.012 & 0.132 & 0.084 \\
\hline & $\delta^{13} \mathrm{C}$ & -0.022 & 0.010 & -0.001 & -0.043 \\
\hline & $\delta^{15} \mathrm{~N}$ & -0.003 & -0.006 & 0.010 & -0.016 \\
\hline \multirow[t]{6}{*}{$\mathrm{Ni}\left(\mathrm{mg} \cdot \mathrm{kg}^{-1}\right)$} & Intercept & -1.381 & 1.684 & 1.987 & -4.750 \\
\hline & Season & 0.149 & 0.149 & 0.446 & -0.149 \\
\hline & Fork length & $3.160 \times 10^{-3}$ & $5.767 \times 10^{-3}$ & $1.470 \times 10^{-2}$ & $-8.400 \times 10^{-3}$ \\
\hline & Age & $7.027 \times 10^{-3}$ & $1.402 \times 10^{-2}$ & $3.509 \times 10^{-2}$ & $-2.100 \times 10^{-2}$ \\
\hline & Condition & -0.011 & 0.024 & 0.037 & -0.060 \\
\hline & $\delta^{15} \mathrm{~N}$ & -0.011 & 0.022 & 0.032 & -0.054 \\
\hline \multirow[t]{8}{*}{$\mathrm{Pb}\left(\mathrm{mg} \cdot \mathrm{kg}^{-1}\right)$} & Intercept & -3.996 & 1.217 & -1.562 & -6.431 \\
\hline & Season & 0.015 & 0.032 & 0.079 & -0.048 \\
\hline & Age & -0.011 & 0.018 & 0.038 & -0.060 \\
\hline & Condition & -0.565 & 0.305 & 0.046 & -1.177 \\
\hline & $\delta^{13} \mathrm{C}$ & -0.164 & 0.048 & -0.068 & -0.259 \\
\hline & $\delta^{15} \mathrm{~N}$ & $-8.725 \times 10^{-5}$ & 0.063 & 0.126 & -0.127 \\
\hline & Age $* \delta^{15} \mathrm{~N}$ & -0.043 & 0.020 & -0.002 & -0.083 \\
\hline & Condition $* \delta^{15} \mathrm{~N}$ & -0.562 & 0.255 & -0.052 & -1.072 \\
\hline
\end{tabular}


Table 5 Summary of the composite models (parameter and interaction term estimates $(\widetilde{\bar{B}})$, unconditional standard errors $(\hat{s} e(\widetilde{\bar{B}})$ ), and upper (UCI) and lower (LCI) $95 \%$ confidence intervals), determined through model averaging, that best describe liver concentrations of essential $(\mathrm{Cu}$ and $\mathrm{Zn})$ and non-essential metals $(\mathrm{As}, \mathrm{Cd}, \mathrm{Cr}, \mathrm{Cu}, \mathrm{Ni}$, and $\mathrm{Pb})$

\begin{tabular}{|c|c|c|c|c|c|}
\hline Element & Parameter & $\widetilde{\widetilde{B}}$ & $\hat{s} e(\widetilde{\bar{B}})$ & $\overline{\mathrm{UCI}}$ & LCI \\
\hline \multirow[t]{8}{*}{$\mathrm{Cu}\left(\mathrm{mg} \cdot \mathrm{kg}^{-1}\right)$} & Intercept & 5.821 & 0.973 & 7.768 & 3.875 \\
\hline & Season & 0.237 & 0.046 & 0.328 & 0.146 \\
\hline & Fork length & $2.095 \times 10^{-3}$ & $3.142 \times 10^{-2}$ & $4.190 \times 10^{-2}$ & $-8.400 \times 10^{-3}$ \\
\hline & Condition & 0.097 & 0.214 & 0.524 & -0.331 \\
\hline & $\delta^{13} \mathrm{C}$ & 0.164 & 0.035 & 0.235 & 0.094 \\
\hline & $\delta^{15} \mathrm{~N}$ & -0.067 & 0.053 & 0.040 & -0.173 \\
\hline & Season*Condition & 0.289 & 0.340 & 0.970 & -0.392 \\
\hline & Season $* \delta^{13} \mathrm{C}$ & -0.082 & 0.035 & -0.012 & -0.151 \\
\hline \multirow[t]{7}{*}{$\overline{\mathrm{Zn}\left(\mathrm{mg} \cdot \mathrm{kg}^{-1}\right)}$} & Intercept & 3.424 & 0.339 & 4.101 & 2.745 \\
\hline & Season & -0.003 & 0.007 & 0.011 & -0.017 \\
\hline & Fork length & $-3.753 \times 10^{-3}$ & $1.449 \times 10^{-3}$ & $-8.600 \times 10^{-5}$ & $-6.700 \times 10^{-3}$ \\
\hline & Condition & -0.250 & 0.085 & -0.079 & -0.421 \\
\hline & $\delta^{13} \mathrm{C}$ & 0.039 & 0.013 & 0.065 & 0.013 \\
\hline & $\delta^{15} \mathrm{~N}$ & -0.013 & 0.017 & 0.022 & -0.047 \\
\hline & Fork length $* \delta^{15} \mathrm{~N}$ & $1.074 \times 10^{-3}$ & $1.300 \times 10^{-3}$ & $3.670 \times 10^{-3}$ & $-1.500 \times 10^{-3}$ \\
\hline \multirow[t]{7}{*}{$\overline{A s}\left(\mathrm{mg} \cdot \mathrm{kg}^{-1}\right)$} & Intercept & -1.272 & 3.011 & 4.753 & -7.296 \\
\hline & Season & -0.429 & 0.133 & -0.163 & -0.695 \\
\hline & Age & -0.054 & 0.054 & 0.055 & -0.163 \\
\hline & Condition & 0.052 & 0.129 & 0.309 & -0.206 \\
\hline & $\delta^{13} \mathrm{C}$ & -0.122 & 0.128 & 0.133 & -0.377 \\
\hline & $\delta^{15} \mathrm{~N}$ & 0.097 & 0.130 & 0.357 & -0.164 \\
\hline & Age $* \delta^{15} \mathrm{~N}$ & 0.011 & 0.021 & 0.053 & -0.032 \\
\hline \multirow[t]{5}{*}{$\overline{\mathrm{Cd}\left(\mathrm{mg} \cdot \mathrm{kg}^{-1}\right)}$} & Intercept & 0.571 & 0.433 & 1.438 & -0.295 \\
\hline & Season & 0.051 & 0.045 & 0.140 & -0.039 \\
\hline & Fork length & $-8.789 \times 10^{-5}$ & $2.444 \times 10^{-3}$ & $4.010 \times 10^{-3}$ & $-5.800 \times 10^{-3}$ \\
\hline & Age & 0.011 & 0.015 & 0.040 & -0.019 \\
\hline & Condition & -0.809 & 0.215 & -0.380 & -1.239 \\
\hline
\end{tabular}




\begin{tabular}{|c|c|c|c|c|c|}
\hline & $\delta^{15} \mathrm{~N}$ & -0.010 & 0.049 & 0.088 & -0.108 \\
\hline & Fork length* $\delta^{15} \mathrm{~N}$ & $5.423 \times 10^{-3}$ & $4.521 \times 10^{-3}$ & $1.477 \times 10^{-2}$ & $-3.600 \times 10^{-3}$ \\
\hline & $\operatorname{Age}^{*} \delta^{15} \mathrm{~N}$ & 0.011 & 0.015 & 0.041 & -0.020 \\
\hline & Condition $* \delta^{15} \mathrm{~N}$ & 0.173 & 0.191 & 0.556 & -0.210 \\
\hline \multirow[t]{6}{*}{$\mathrm{Cr}\left(\mathrm{mg} \cdot \mathrm{kg}^{-1}\right)$} & Intercept & -0.289 & 0.321 & 0.353 & -0.930 \\
\hline & Season & 0.068 & 0.009 & 0.086 & 0.050 \\
\hline & Condition & -0.075 & 0.056 & 0.037 & -0.186 \\
\hline & $\delta^{13} \mathrm{C}$ & -0.001 & 0.005 & 0.009 & -0.011 \\
\hline & $\delta^{15} \mathrm{~N}$ & 0.002 & 0.004 & 0.011 & -0.007 \\
\hline & Season*Condition & -0.006 & 0.015 & 0.023 & -0.035 \\
\hline \multirow[t]{5}{*}{$\mathrm{Ni}\left(\mathrm{mg} \cdot \mathrm{kg}^{-1}\right)$} & Intercept & -0.335 & 0.181 & 0.027 & -0.670 \\
\hline & Season & -0.073 & 0.026 & -0.021 & -0.125 \\
\hline & Age & 0.008 & 0.009 & 0.026 & -0.010 \\
\hline & Condition & -0.458 & 0.170 & -0.117 & -0.798 \\
\hline & Season*Condition & 0.069 & 0.123 & 0.315 & -0.177 \\
\hline \multirow[t]{7}{*}{$\mathrm{Pb}\left(\mathrm{mg} \cdot \mathrm{kg}^{-1}\right)$} & Intercept & -1.019 & 0.340 & -0.339 & -1.699 \\
\hline & Season & 0.120 & 0.037 & 0.194 & 0.046 \\
\hline & Condition & -0.471 & 0.231 & -0.009 & -0.932 \\
\hline & $\delta^{13} \mathrm{C}$ & -0.004 & 0.009 & 0.014 & -0.021 \\
\hline & $\delta^{15} \mathrm{~N}$ & -0.003 & 0.011 & 0.018 & -0.024 \\
\hline & Season*Condition & 0.058 & 0.117 & 0.292 & -0.176 \\
\hline & Condition $* \delta^{15} \mathrm{~N}$ & -0.068 & 0.118 & 0.168 & -0.304 \\
\hline
\end{tabular}




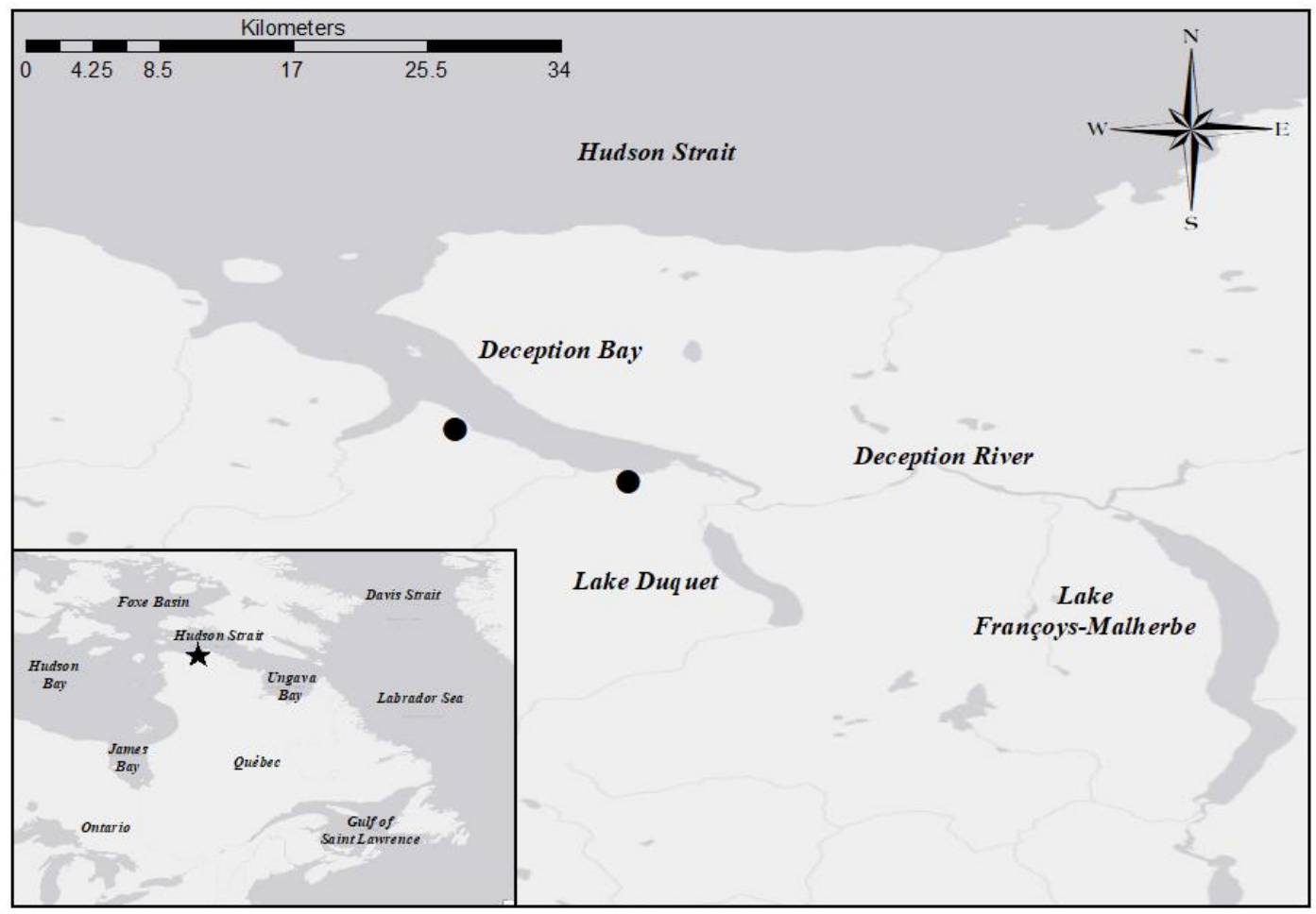

Fig. 1 Map of the Deception River system, including the three main sampling areas: Deception Bay, and lakes Duquet and Françoys-Malherbe. Black circles represent current mining operations present in the area, while the black star visible on the map in the lower left-hand corner represents the sampling locations in relation to the Province of Québec in eastern Canada 
Post-Winter As

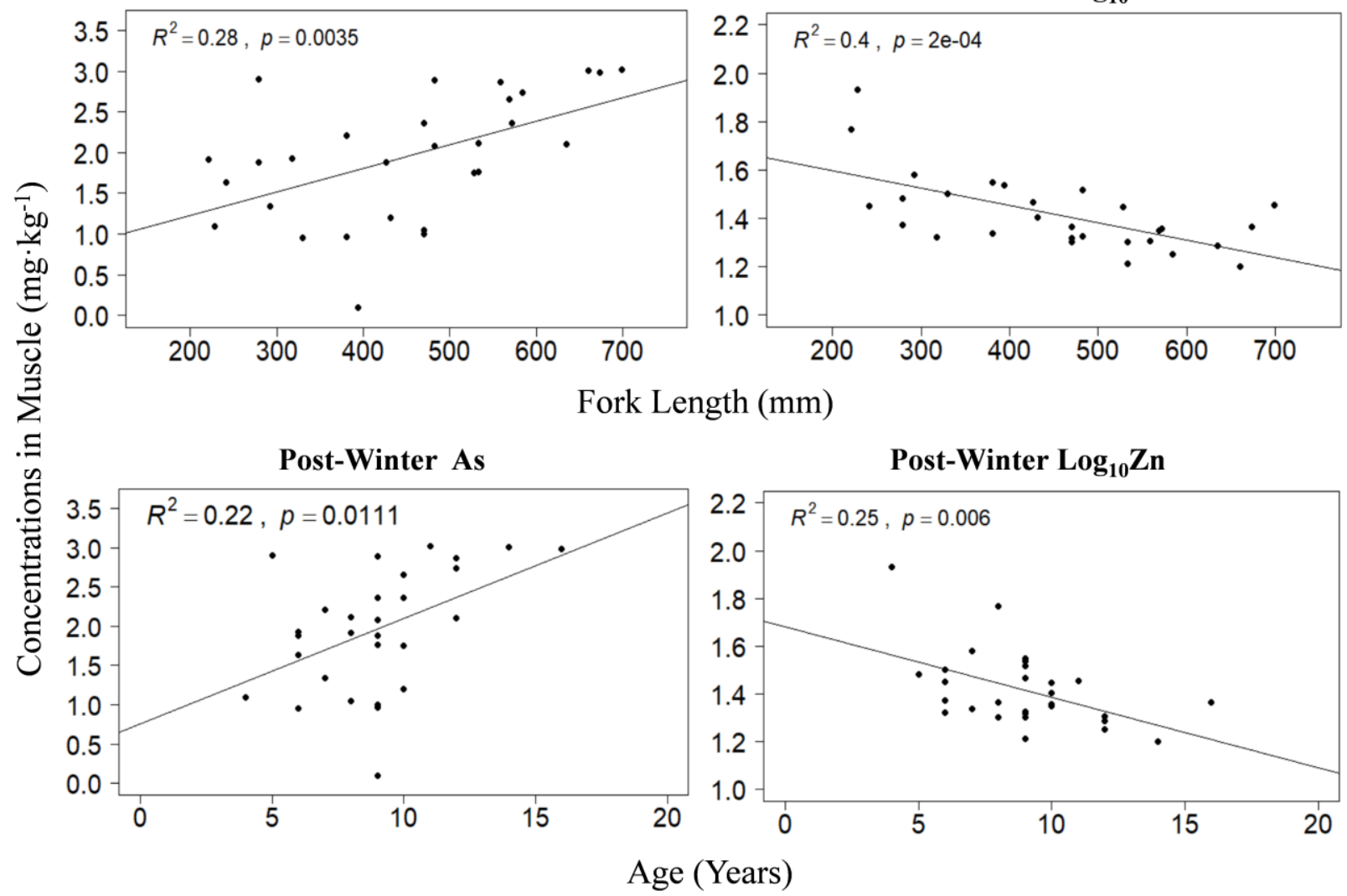

Fig. 2 Significant dorsal muscle concentrations of anadromous Deception River Arctic charr captured in the marine environment in summer and in freshwater lakes during the post-winter in relation to biological variables (fork length, age, and somatic condition measurements) 

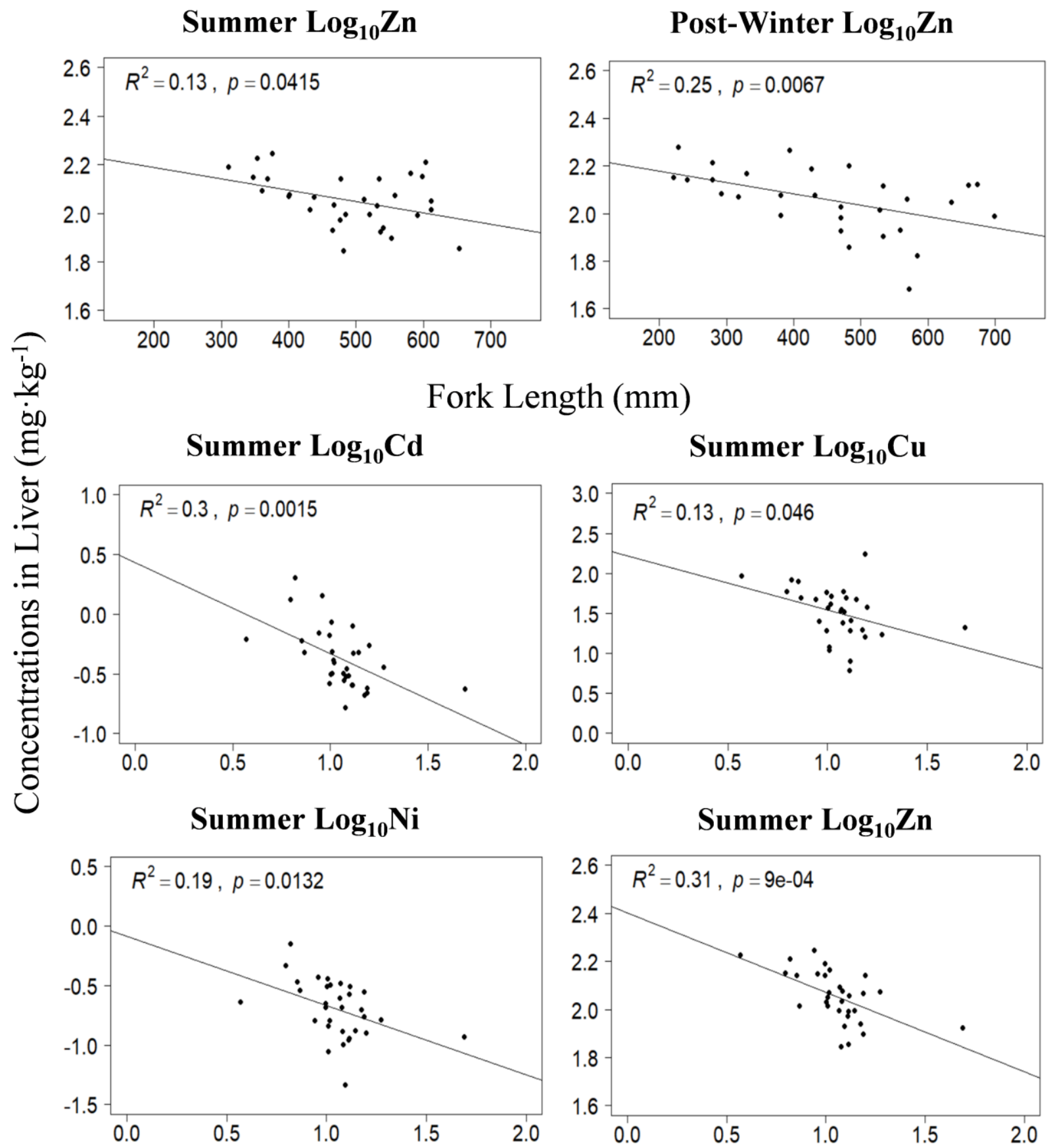

Summer $\log _{10} \mathrm{Zn}$

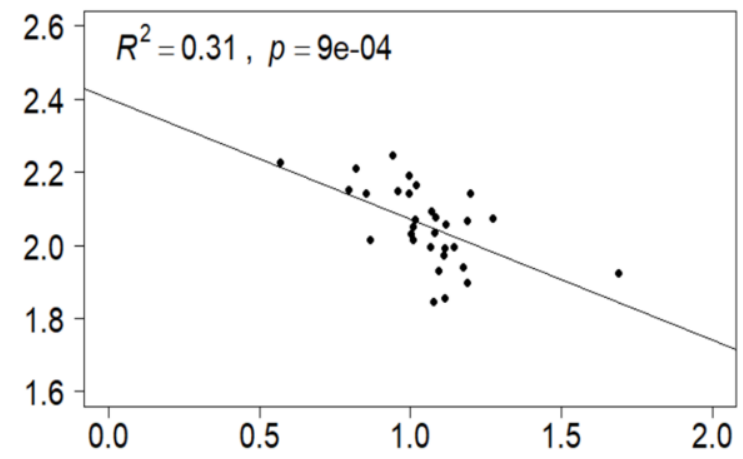

\section{Somatic Condition (K)}

Fig. 3 Significant liver concentrations of anadromous Deception River Arctic charr captured in the marine environment in summer and in freshwater lakes during the post-winter in relation to biological variables (fork length, age, and somatic condition measurements 
Post-Winter $\log _{10} \mathrm{~Pb}$

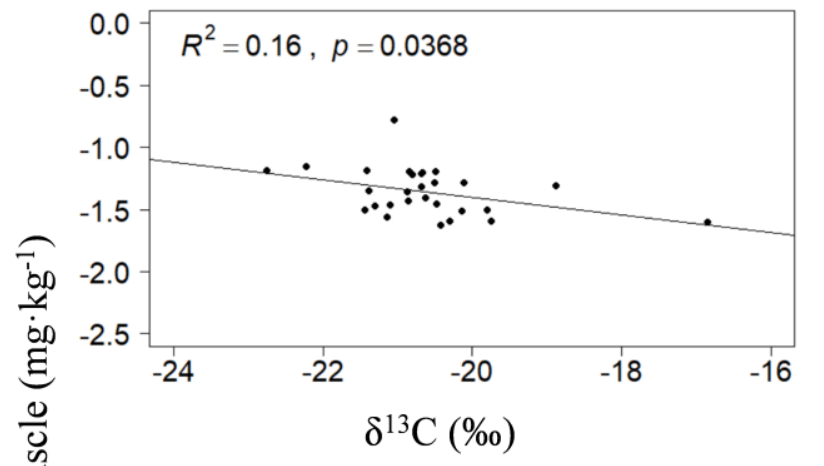

Summer $\log _{10} \mathrm{Cr}$

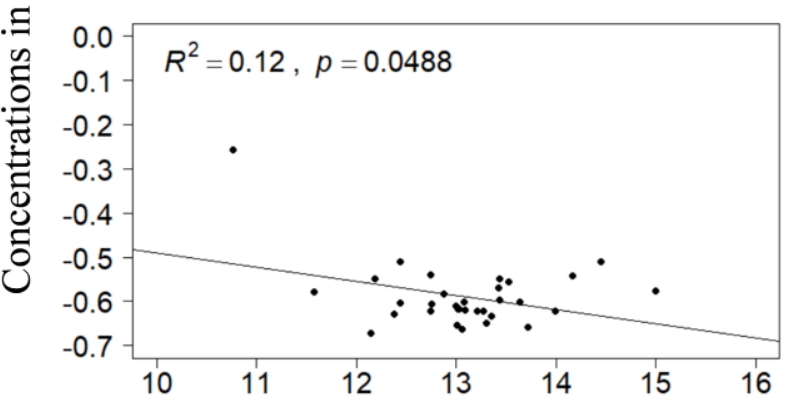

Post-Winter As

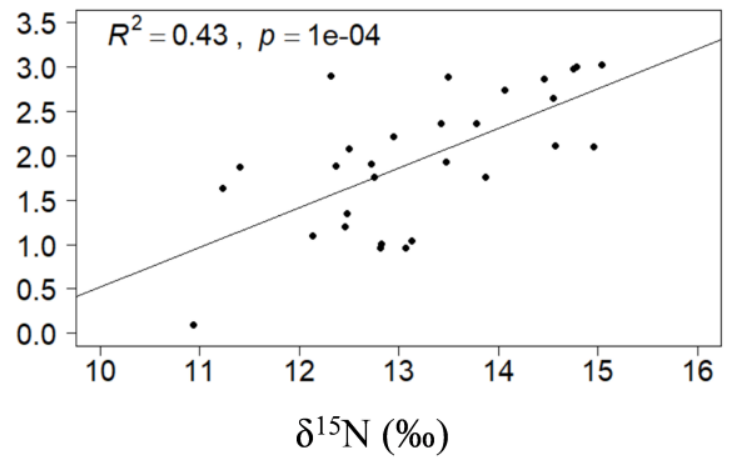

Post-Winter $\log _{10} \mathrm{Zn}$

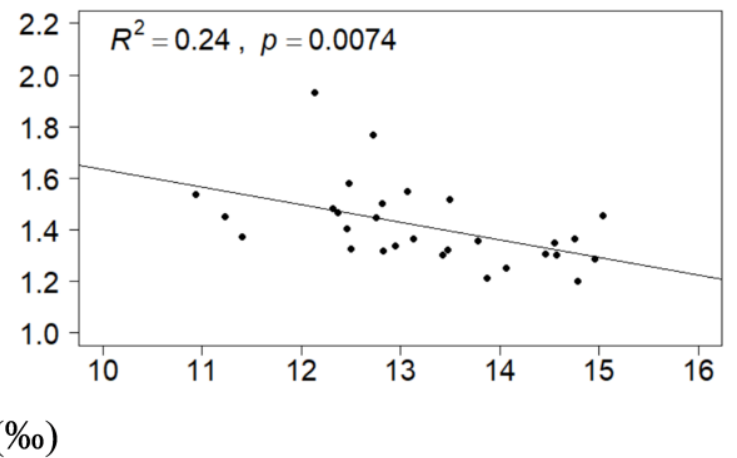

Fig. 4 Significant dorsal muscle concentrations of anadromous Deception River Arctic charr captured in the marine environment during the summer and in the freshwater during the post-winter in relation to stable isotope values $\left(\delta^{13} \mathrm{C}\right.$ and $\left.\delta^{15} \mathrm{~N}\right)$ 


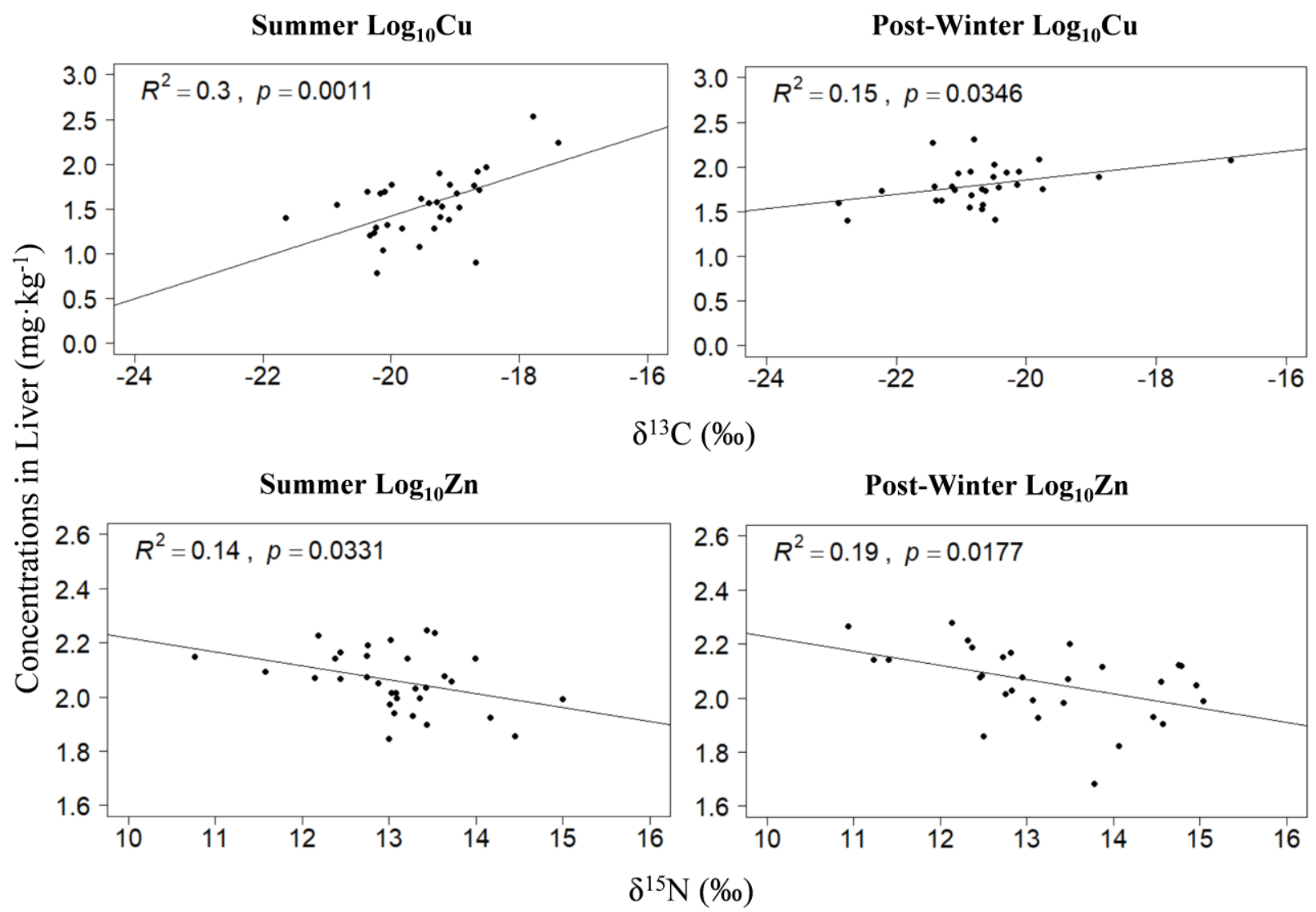

Fig. 5 Significant liver concentrations of anadromous Deception River Arctic charr captured in the marine environment during the summer and in the freshwater during the post-winter in relation to stable isotope values $\left(\delta^{13} \mathrm{C}\right.$ and $\left.\delta^{15} \mathrm{~N}\right)$ 